\title{
High mountain lakes: extreme habitats and witnesses of environmental changes
}

\author{
Jordi Catalan ${ }^{1,5}$, Lluís Camarero ${ }^{1,5}$, Marisol Felip ${ }^{2,5}$, Sergi Pla ${ }^{3}$, Marc Ventura ${ }^{4}$, \\ Teresa Buchaca ${ }^{4}$, Frederic Bartumeus ${ }^{1,5}$, Guillermo de Mendoza ${ }^{1,5}$, Alexandre Miró ${ }^{5}$, \\ Emilio O. Casamayor ${ }^{1,5}$, Juan Manuel Medina-Sánchez ${ }^{1,5,6}$, Montserrat Bacardit ${ }^{1,5}$, \\ Maddi Altuna ${ }^{1,5}$, Mireia Bartrons ${ }^{1,5}$, Daniel Díaz de Quijano ${ }^{1,5}$ \\ ${ }^{1}$ Centre d'Estudis Avançats de Blanes, CSIC, Blanes, Spain. \\ ${ }^{2}$ Departament d'Ecologia, Universitat de Barcelona, Barcelona, Spain. \\ ${ }^{3}$ Department of Geography, University of Loughborough, Leicestershire, United Kingdom. \\ ${ }^{4}$ National Environmental Research Institute, Silkeborg, Denmark. \\ ${ }^{5}$ Unitat de Limnologia (UB-CSIC). Centre de Recerca d'Alta Muntanya, Universitat de Barcelona, Vielha, Spain. \\ ${ }^{6}$ Departamento de Ecología, Universidad de Granada, Granada, Spain.
}

\begin{abstract}
High mountain lakes offer research opportunities beyond what could be expected from their quantitative relevance in the Earth system. In this article we present a brief summary of the research carried out in the lakes of the Pyrenees in the last twenty years by the group of limnology of the Centre for High Mountain Research (CRAM) of the University of Barcelona. The studies can be included in three main topics: life in extreme conditions, catchment-lake relationships and environmental changes.
\end{abstract}

Keywords: alpine lakes, extreme habitats, catchment-lake relationships, long-range atmospheric pollution, climate change.

\section{RESUMEN}

Los lagos de montaña ofrecen oportunidades de estudio que van mucho más allá de lo que su disposición en el territorio y abundancia pudieran sugerir. En este artículo presentamos un breve resumen de los temas que hemos abordado a lo largo de poco más de veinte años de investigación en los lagos de los Pirineos por parte del grupo de limnología del Centro de Investigaciones de Alta Montaña (CRAM) de la Universidad de Barcelona. Los estudios se enmarcan fundamentalmente en tres líneas generales: la vida en condiciones extremas, las relaciones cuenca-lago y los cambios ambientales.

Palabras clave: lagos alpinos, vida en hábitats extremos, relaciones cuenca-lago, contaminación atmosférica difusa, cambio climático.

\section{INTRODUCTION}

High mountain lakes are among the ecosystems with larger similarities throughout the planet. The low permeability of crystalline bedrocks favours the presence of lakes and, because orogenesis is the main source of this bedrock type, most of the large and high ranges of the World (the Alps, the Pyrenees, Sierra Nevada, the Scandinavian mountains, the Tatras, the Caucasus, the Pamirs, the Hindu Kush, Karakorum, Himalayas, Rocky Mountains, the Andes, the Kenya, Rwenzori, Kili- manjaro, the Carsteusz mountains, Ruapehu, among others) have an associated lake district. Most of the existing high mountain lakes originated during the last glaciation due to the action of ice upon those hard bedrocks, therefore, mountain lakes are generally young ecosystems. Despite their apparent marginal role in the Earth system, high-mountain lakes are particularly suitable for studies on certain environmental and ecological topics, and for this reason, the scientific community have paid attention to them beyond to what could be expected from their quantitative relevance. 
Our group started these type of studies in the early 80 's, when Dr. Margalef suggested to study some lake in the Pyrenees taking advantage of the new field station built by the University of Barcelona in the Central Pyrenees (Centre de Recerca d'Alta Muntanya, CRAM). In this paper, we summarise some of the studies carried out by our group in the high mountain lakes of the Pyrenees, particularly, on Lake Redon (formerly Lake Redó) ( $42^{\circ}$ $38^{\prime} \mathrm{N}$, 0o 46'E, $2240 \mathrm{~m}$ a.s.1.). Our research interests, initially focused on planktonic lake processes, grew and diversified progressively as the number of members of the group increased. As a consequence, the themes addressed in this paper may appear miscellaneous at first glance, but they actually give account of our activities in three main research areas in which high mountain lakes are particularly suitable as field sites or model systems.

The particular location of high mountain lakes determines a number of environmental conditions that are traditionally considered extreme for life. Low rock weathering and limited soil development determine highly diluted waters, both in major salt components and nutrients. As a consequence, organisms face challenges related to that extreme dilution: osmoregulation, oligotrophy, low encountering rates, etc. On the other hand, altitude is a factor of multiple consequences. Because the thinner atmosphere, radiation and particularly the UV-B fraction increases, thus lake biota is alternatively subjected to harmful high radiations during the ice free period and to light limited conditions in winter. The formation and development of an ice and snow cover, which may last for many months, is a distinctive dynamical feature of these lake ecosystems. Finally, altitude also determines remoteness, if colonisation may be a general key process in assembling local communities of organisms, in high mountain lakes it may become even more relevant because the headwater nature of the lakes, high elevation watersheds and relative isolation of the mountain ranges in a matrix of low land territory. The degree of those extreme conditions changes from place to place and, thus, high mountain lake districts are usually a mosaic of highly divers lakes, diversity which is highly coherent with the characteristics of their catchments, because mountain lakes are small water bodies where matter loadings from the catchment are fundamental in determining the lake characteristics. Catchments are relatively small compare to low land lakes, as a consequence, atmospheric loadings tend to be also significant to determine the characteristics of water runoff, and thus lake water ones. If we combine the sensitivity of mountain lake ecosystems to external forcing with their remoteness from areas of high human activity, it turns out that high mountain lakes are excellent sentinels and recorders of past and present environmental changes. In summary, high mountain lakes are particularly suitable for studies on life in extreme environments, lakecatchment interactions and large-scale environmental changes. The manuscript is organized in brief accounts of our past and present activities in those three main research fields.

\section{EXTREME HABITATS}

\section{Living in highly diluted waters}

\section{Species segregation}

Rock weathering of crystalline bedrocks is extremely slow, particularly, if soil development is scarce or null, as a consequence, high mountain lake waters are poor in dissolved salts. This salt dilution has some biological consequences of different nature. In extreme cases, it may result in a physiological limitation for survival, such as what happens to fish in the lakes with the lowest calcium concentrations. More often, variation in major water components results in species segregation, particularly, with primary producers. It is well known how diatom species segregate along $\mathrm{pH}$ gradients related to changes in acid neutralising capacity (ANC) (Battarbee et al., 2001), which in turn is mostly due to $\mathrm{Ca}^{2+}$ concentration, the main cation produced by chemical weathering of a large variety of rocks (Psenner \& Catalan, 1994). In the studies carried out in the 
Pyrenees, it was also found that the main environmental axis of segregation for chrysophytes was related to ANC, and thus to bedrock nature of the catchments (Pla et al., 2003). The segregation throughout the ANC gradient is not restricted to microalgal forms. Among macrophytes, isoetids (Isoetes lacustris, I. setacea, Subularia aquatica) prevailed in softwater lakes and potamids (Potamogeton spp., Ranunculus spp.) in relatively hardwater lakes (Gacia et al., 1994).

\section{Microbial life}

The low salt content also applies to microcomponents of the water chemical composition. High mountain lakes are usually oligotrophic, phytoplankton growth is limited and thus water transparency is high. Nevertheless, a rich microplanktonic community is commonly present, in which species composition and biomass values vary seasonally driven by the changes in the physical forcing of the lake and internal dynamics of the planktonic community (Felip et al., 1999a; Felip \& Catalan, 2000). Although there is a large variability, characteristic biomass ratios between the distinct microplankton components are 10:2:2:1, for phytoplankton, bacteria, hetero- trophic flagellates and ciliates, respectively (Felip et al., 1999a). During winter the percentage of strict heterotrophic biomass increases and protozoa become eventually dominant (Fig. 1). A relevant fraction of phytoplankton in high mountain lakes is composed of mixotrophic organisms (Gymnodinium, Chromulina, Ochromonas, Dinobryon, Cryptomonas), which can behave either as autotrophs or heterotrophs. Bacterial abundance and biomass are usually low compared to other lakes and show little change throughout the year. Some size segregation can occur when the lake is stratified, with larger bacteria appearing in the upper layers (Felip et al., 1999a). The use of modern molecular techniques to identify bacterial populations has recently demonstrated large diversity of prokaryotes in high mountain lake plankton. The variability of the distinct groups clearly exceeds the fluctuations of the total bacterial assemblage, suggesting that the stability of total abundances do not properly reflect a highly dynamic planktonic component (Pernthaler et al., 1998). The information is still scarce, nevertheless it appears noteworthy the dominance of Actinobacteria groups and the common presence of Archaea (Warnecke et al., 2005; Medina-Sánchez et al.,

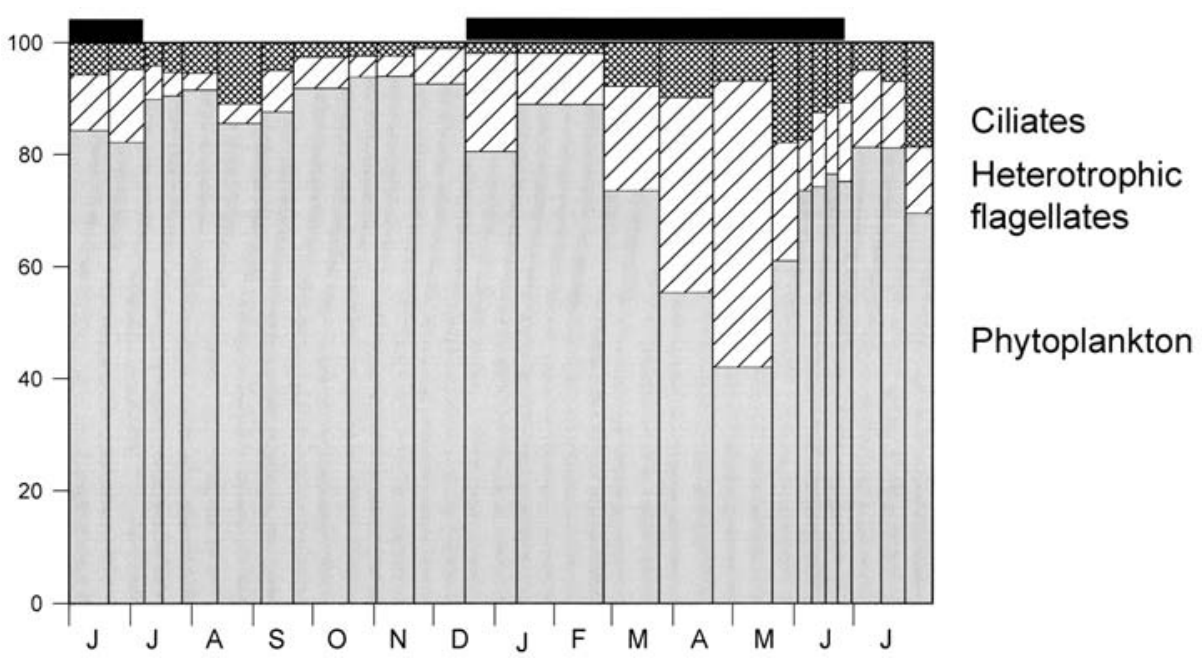

Figure 1. Microplankton biomass distribution (\% of carbon content) among phytoplankton, heterotrophic flagellates and ciliates in Lake Redon (Pyrenees) during a complete seasonal cycle of 1984-85. Distribución de la biomasa en el microplancton (\% de contenido en carbono) entre fitoplancton, flagelados heterotróficos y ciliados en el Lago Redon (Pirineos) durante un ciclo estacional completo, 1984-85. 
2005). Future research in microplankton interactions and dynamics points to applying a singlecell approach. But these ultraoligotrophic environments are not always the most suitable to be single-cell analysed, so a methodological effort is being made in adapting techniques such as CARD-FISH (Catalysed Reporter DepositionFluorescent In Situ Hybridisation) (MedinaSánchez et al., 2005), ELF97 phosphate substrate (Enzyme-Labelled Fluorescence) and MAR-FISH (Micro AutoRadiography-FISH), without disregarding possible improvements in XRMA (X-Ray Micro Analysis) or the combination of some of these techniques.

\section{Oligotrophy}

According to the total phosphorus (TP) concentration measured on a survey performed along the Pyrenees in summer year 2000, more than $70 \%$ of the lakes could be classified as ultraoligotrophic (TP $<4.7 \mu \mathrm{g} \mathrm{L}^{-1}$ ), $22 \%$ as oligotrophic $\left(4.7<\mathrm{TP}<9.3 \mu \mathrm{g} \mathrm{L}^{-1}\right)$ and $6 \%$ as mesotrophic $\left(9.3<\mathrm{TP}<31 \mu \mathrm{g} \mathrm{L}^{-1}\right)$. The algal group composition estimated using pigment-based methods along the surveyed lakes showed that cryptophytes were associated to lakes with greater phosphorus concentration whereas chrysophytes predominate at the opposite extreme of the trophic gradient (Buchaca, 2005). The other typically present algal groups (chlorophytes, diatoms, dinoflagellates) and cyanobacteria were independent of the trophic gradient. Studies carried out in Lake Redon showed that the seasonal phytoplankton dynamics was driven by light availability and internal nutrient loading related to mixing patterns, following the typical pattern in oligotrophic lakes with production maxima when mixing reaches the depth where the fine and nutrient rich sediment is located (below $25 \mathrm{~m}$ in the particular case of Lake Redon) (Catalan \& Camarero, 1991). Despite the existence of a large inter-annual variability, four main production phases are typically present in those alpine lakes (Ventura et al., 2000; Catalan et al., 2002b), with varying relative intensity: spring and autumn overturns, upper hypolimnion during summer stratification and under the ice at the beginning of the icecovered period. The four periods have contrasting combinations of nutrient and light regimes, which lead to particular acclimation responses by phytoplankton, such as changes in cell pigment content and pigment ratios (Felip \& Catalan, 2000; Buchaca, 2005).

\section{Stoichiometry}

High mountain lakes are not only nutrient poor but also there is usually a large elemental imbalance respect the ideal proportions for life. The intra-specific and inter-specific variability in elemental composition of organisms provides a method to compare life histories in a common ecological stoichiometry framework (Sterner \& Elser, 2002). In a recent study, we compared the life histories of the three crustacean zooplankton species of Lake Redon (a cladoceran, Daphnia pulicaria, a cyclopoid copepod, Cyclops abyssorum, and a calanoid copepod, Diaptomus cyaneus) (Ventura \& Catalan, 2005). The three species had contrasting reproduction strategies, although they were all iteroparous annual species. The production of a single cohort was a common feature, while they differed in their diapausing strategy. Daphnia showed both diapausing and non-diapausing strategies. Coinciding with the end of the autumn overturn and the start of the ice-cover, adult males appeared and ephippia were subsequently produced. However, most adult females survived below the ice-cover, waiting to reproduce until next ice-free period. Cyclops adults also survived below the ice-cover, probably synchronising its life cycle with the Daphnia, as the former prey on the latter (Gliwicz et al., 2001). Diaptomus was the only strict diapausing species, completing its life cycle within a short period. In Lake Redon, Diaptomus emergence coincided with the spring production maxima and during their presence in the plankton of the lake they completely dominated the zooplankton biomass. The elemental composition of the three species was typical of crustacean zooplankton, having the two copepods higher nitrogen and lower phosphorus content than the cladoceran. However, the three spe- 
cies had relatively high carbon content, as a result of being enriched in lipid content, as has also been found in marine copepods inhabiting cold areas (Lee \& Hirota, 1973). Daphnia had also a relatively low phosphorus content compared with other species of the same genus, which has been interpreted as an adaptation to inhabit an ultra-oligotrophic environment such as Lake Redon. For the three species, reproduction was the main cause of intra-specific elemental variability (Fig. 2). Adult females of the three species lost from 32 to $48 \%$ of their initial absolute C and $\mathrm{H}$ content during reproduction, which corresponded to a similar decrease in their lipid and carbohydrate content. The $\mathrm{N}$ content did not change in any of the three species; nor did the protein and chitin content. Daphnia and Diaptomus lost $35 \%$ and $56 \%$, respectively, of their initial absolute $\mathrm{P}$ content during reproduction, while Cyclops' $\mathrm{P}$ content did not change. The three species stored energy compounds under unfavourable conditions for later use in offspring production, but only Diaptomus and Daphnia mobilised stored P. Corresponding stoichiometric changes with reproduction included (Fig. 2): a decrease in C:N ratio for the three spe-

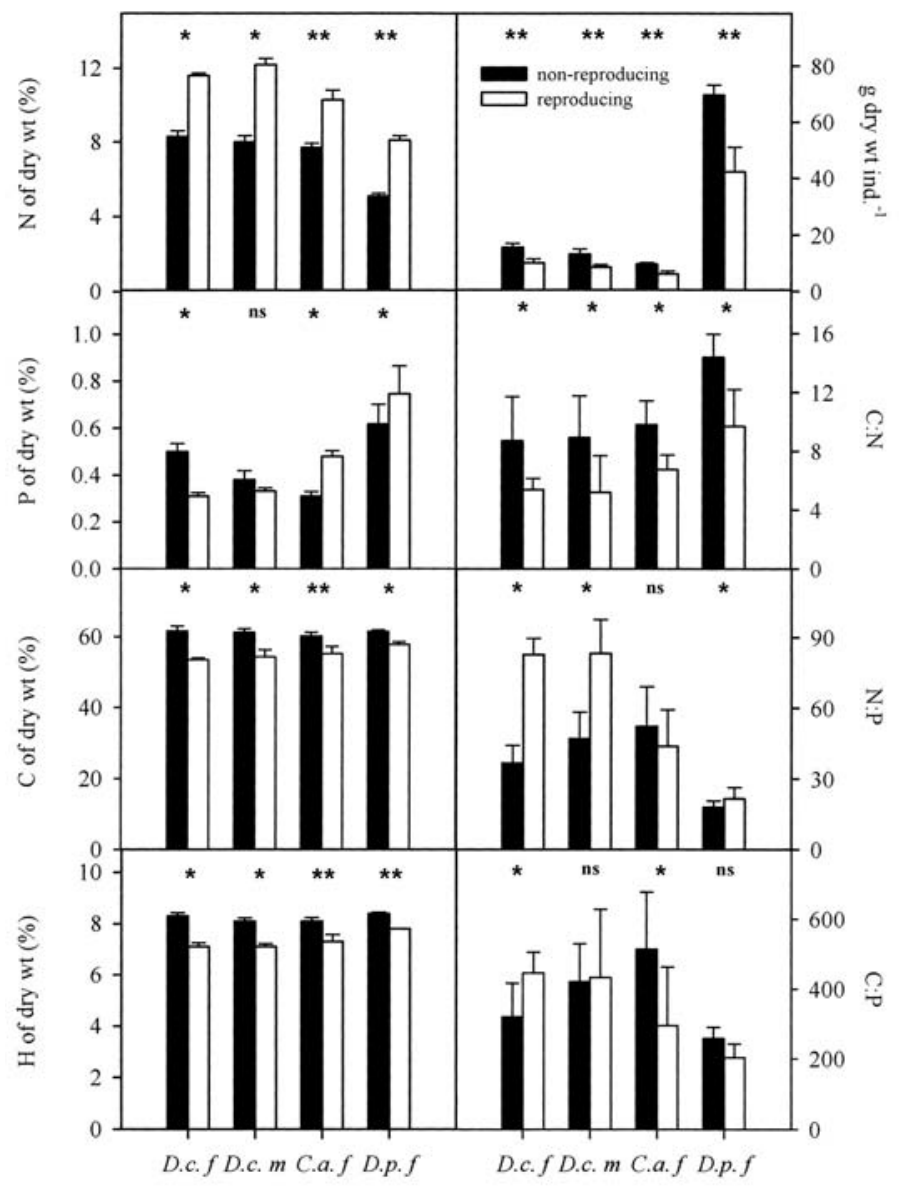

Figure 2. Dry weight, elemental content, and atomic ratios (by atoms) before and after reproduction for adult females of Diaptomus cyaneus (D.c.f.), Cyclops abyssorum (C.a.f.) and Daphnia pulicaria (D.p.f.) and adult males of Diaptomus cyaneus (D.c.m.) from Lake Redon. * and ** indicates significant differences between before and during/after reproduction at $p<0.05$ and $p$ $<0.005$, respectively; $\mathrm{ns}=$ not significant. Modified from Ventura and Catalan (2005). Peso seco, contenido elemental y relaciones atómicas (en átomos) antes y después de la reproducción en hembras adultas de Diaptomus cyaneus (D.c.f.), Cyclops abyssorum (C.a.f.) y Daphnia pulicaria (D.p.f.) y machos adultos de Diaptomus cyaneus (D.c.m.) en el lago Redon. * $y$ ** indican las diferencias significativas entre antes y después de la reproducción a $\mathrm{p}<0.05$ y $\mathrm{p}<0.005$, respectivamente; ns $=$ no significativo. Modificado de Ventura \& Catalan (2005). 
cies; an increase in N:P ratio for Daphnia adult females and adults of Diaptomus; and a C:P ratio increase in Diaptomus females and decline in Cyclops females. Differences in C:P ratio changes corresponded with differences in allocation to their respective reproductive tissues. Diaptomus males and Daphnia females did not change their $\mathrm{C}: \mathrm{P}$ ratio with reproduction. The elemental composition of adult males differed between the three species. The dry weight of adult Cyclops did not change significantly during the period they were present in the lake and, as for Daphnia, their composition remained the same as that of pre-adult instars. In contrast, the dry weight of Diaptomus adult males decreased and their elemental composition changed similarly to that of adult females during reproduction (Fig. 2); thus, they yielded a reproduction effort comparable to that of adult females. The reason for these differences is probably related to a difference in mating requirements of the two copepod groups. Cyclopoid females need to be impregnated only once during their lifetimes (Whitehouse and Lewis, 1973), while most calanoid females, however, must mate repeatedly in order to maintain their fertility (Watras and Haney, 1980). This study of the three crustaceans is a good example on how elemental economy in organisms is tied to life-strategies, establishing a bridge between demographic and biogeochemical approaches to ecosystem dynamics.

\section{Encounter rates}

Quality of food is important, but even more critical can be to find that food. In extremely oligotrophic environments, the density of organism is quite low and consumers face a first problem, finding their food. Hence, encounter rates play a central position in foraging theory (Jumars, 1993). Encounter rates also govern reaction rates of ecosystems by determining which and how many individuals, populations, and/or species can interact strongly with each other at specific locations. Despite of their relevance the existence, and possible consequences, of limitation in the rate of encounters is not thoroughly addressed in ecological studies. Overall, low concentra- tion and/or low sensorial capabilities of organisms in any ecosystem may enhance encounter rate limitation, and thus organisms evolving in such conditions might experience specific selection pressures and new adaptive pathways. In classical population biology, ecological dynamics rely on the assumption of perfectly mixed interacting entities in a spaceless world. The socalled mean field assumption, implies that encounter rates are driven exclusively by changes in the density of the interacting entities (Levin \& Durret, 1996). However, some authors, inspired in planktonic interactions in diluted environments, have studied encounter rates by means of equations that consider explicit geometrical representations of the encounter scenario together with some physical insights into the process of encounter, e.g., size and velocity of the interacting particles (Gerritsen \& Strickler, 1977; Rothschild \& Osborn, 1988; MacKenzie \& Kiorboe, 1995; Kiorboe, 1997; Catalan, 1999). Although these encounter rate equations investigate encounter rates beyond changes in density, they do not take explicitly into account the statistical properties emerging from particle's trajectories (e.g., the chances of covering different regions of space, the probability of revisiting a site, etc.). In particular, the statistical properties of movement are relevant when organisms are involved in random search processes (Viswanathan et al., 1999; Bartumeus et al., 2005). In such situations, organisms must attempt to move in such a way so as to optimise their "chances of locating resources" by increasing their "chances of covering appropriate regions". Typically, the diffusion of particles through space has been addressed by means of random walk models (Okubo, 1980; Berg, 1983). Different classes of random walk models involve different types of diffusion and different statistical properties (Mandelbrot, 1977, Shlesinger et al., 1995). Recent studies have shown that the ability to optimise the encounter rates in a random search process can only exist if the motion involves two basic statistical properties: superdiffusion (i.e., root mean square displacement scaling non-linearly with time) and fractality (i.e., power-law move lengths distribution) (Bartumeus et al., 

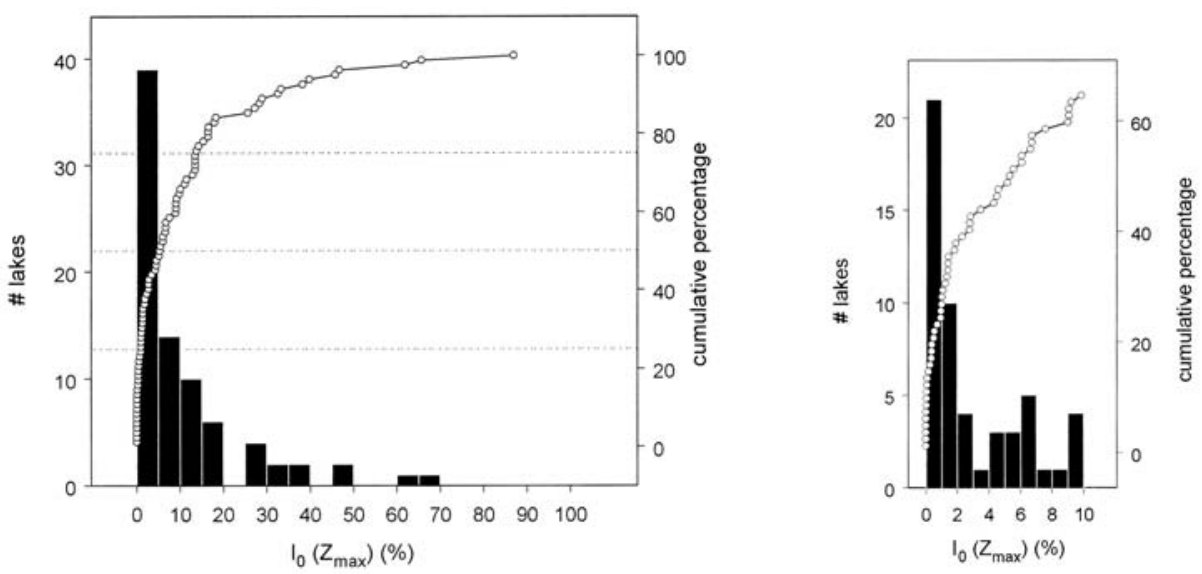

Figure 3. Distributions of the percentage of light reaching the sediment surface at the maximum lake depth $\left(\mathrm{I}_{0}\left(\mathrm{Z}_{\text {max }}\right)\right)$ in the lakes of the Pyrenees during a year 2000 survey. The cumulative percentage is also indicated. Distribución del porcentaje de luz que llega a la superficie del sedimento en la parte más profunda de los lagos $\left(I_{0}\left(Z_{\text {max }}\right)\right)$ de los Pirineos en un muestreo del año 2000 . El porcentaje acumulado también se indica.

2005). A specific class of random walk models, named Lévy walks, incorporates both properties. Such properties allow the emergence of a range of optimal solutions to the encounter problem in different scenarios (Viswanathan et al., 1999; Bartumeus, et al., 2002; Raposo et al., 2003; Santos et al., 2004). Lévy walks properties have been observed in planktonic organisms (Bartumeus et al., 2002) as well as in other types of organism, from protozoa (Levandowsky et al., 1988a; 1988b; 1997; Bartumeus et al., 2003) to mammals (Viswanathan et al., 1996; Atkinson et al., 2002; Austin et al., 2004; Ramos-Fernandez et al., 2004). Overall, these results suggest that some animals may have evolved the ability of performing Lévy walks as adaptive strategies in order to face search uncertainties, and this might be specially relevant in diluted ecosystems.

\section{Irradiance: extremely low, extremely high}

\section{Deep and shallow lakes}

During the ice-free season, light penetration into the water column in high mountain lakes is very high. On a survey performed along the Pyrenees on summer year $2000,75 \%$ of the lakes had more than $1 \%$ subsurface light arriving to the surface of the sediment (Fig. 3). Such light availability supports the development of an autotrophic biofilm in the upper sediment of many of these lakes. The pigment composition of this upper sediments indicates a gradient from autotrophic biofilms (dominated by diatoms and cyanobacteria pigment signals) to heterotrophic biofilms (dominated by cryptophytes, chlorophytes and zooplankton marker pigment signal). The pigment ratio (alloxanthin/diatoxanthin) is a good indicator of the relative contribution to the overall primary production of the two environments (planktonic and benthic) in lakes where diatoms are not a relevant plankton component. The molar ratio between these two marker pigments was positively correlated with lake depth $\left(\mathrm{r}^{2}=0.49\right.$, $p<0.001)$. Thus, in general, we can distinguish between two types of high mountain lakes of contrasting biotic characteristics, shallow lakes (maximum depth $<10-15 \mathrm{~m}$ ) and deep lakes; distinction that is of broadly application to all alpine lakes and constitute an ecological threshold, in the sense that around these lake depth range we find more changes in species communities than above or below them.

\section{Nutrient vs. light limitation}

In high mountain lakes, irradiance is extremely fluctuating between extremely high and low values. These fluctuations happen at seasonal to daily scales, therefore, there is plenty of opportunities to investigate acclimative and adaptive 
responses to those extremes and fluctuations. When lakes freeze, the accumulation of snow on the surface of the lake reduces underwater irradiance below compensatory levels for phytoplankton; condition that may last for several months. However, at the beginning of the ice covered period, $1 \%$ of the subsurface irradiance may reach a depth of $10 \mathrm{~m}$ (Catalan, 1992). In Lake Redon, algae growing below the ice-cover were found to increase the chlorophyll concentration per cell (Felip \& Catalan, 2000; Buchaca et al., 2005), as a photoacclimation response (Geider, 1987). However, samples below the thermocline growing at similar or even lower irradiance values did not show the same response. The ratios between the marker pigments corresponding to each algal group and biovolume were fairly stable for all samples within the photic zone ( $>1 \%$ subsurface irradiance) during the ice free period (Fig. 4). Only in a very few samples below the photic zone did the ratios increase to levels similar to those found in
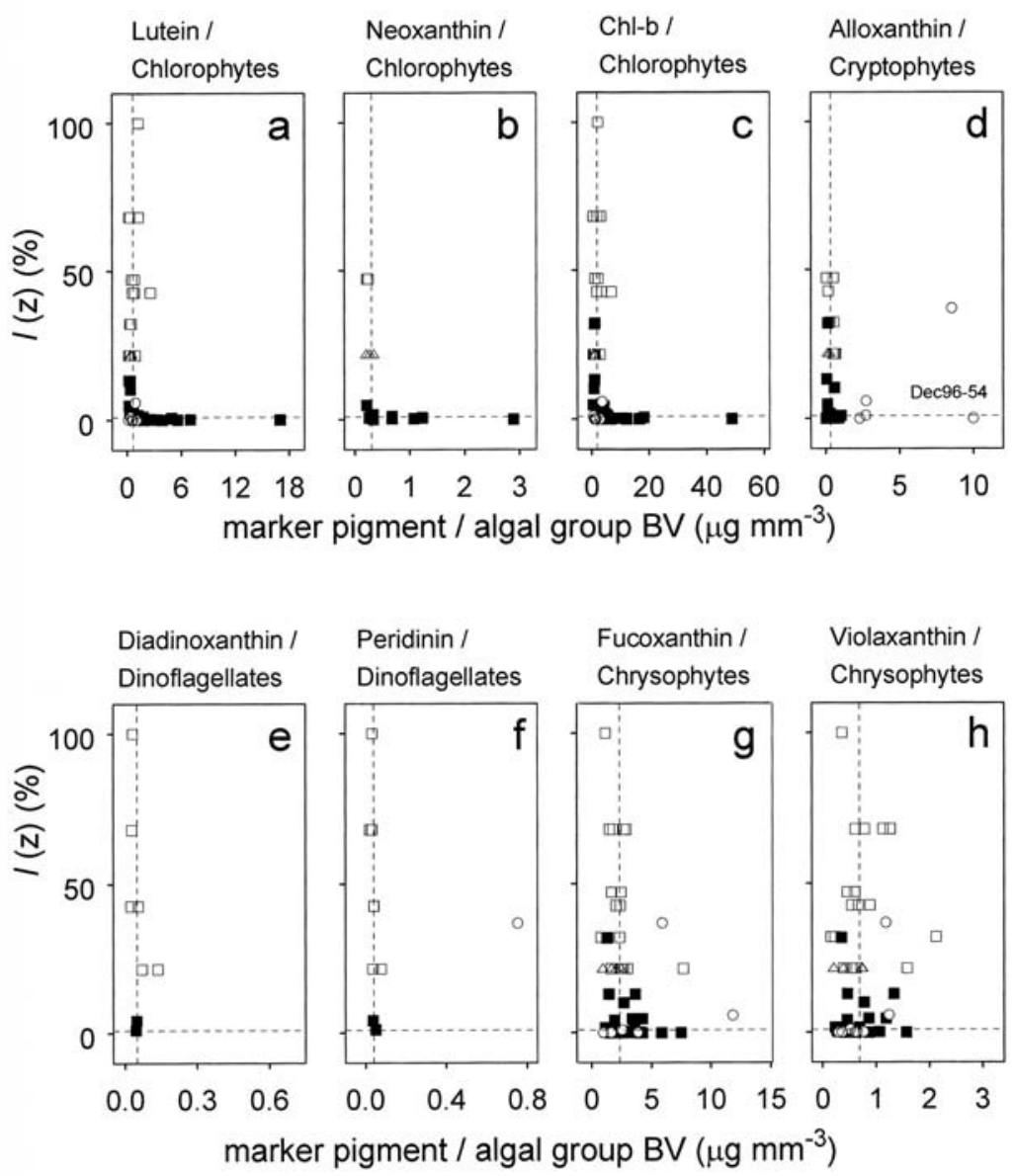

Figure 4. Relationship between ratio values of marker pigment to corresponding algal group biovolume and percentage of subsurface irradiance at the depth of the sample $(I(\mathrm{z}))$. The horizontal dashed line indicates $I(\mathrm{z})=1 \%$, the vertical dashed line represents the calculated mean ratio value for samples above $I(\mathrm{z})=1 \%$. Symbols represent periods of contrasting physical properties in the water column: stratified periods above thermocline (open squares); stratified periods below thermocline (filled squares); during the initial ice-covered period, December-96 (circles) and before ice formation, December-97 (triangles). Relación del cociente entre pigmento indicador y biovolumen algal con el porcentaje de radiación subsuperficial a la profundidad de la muestra $(\mathrm{I}(\mathrm{z}))$. La líneas horizontales discontinuas indican $\mathrm{I}(z)=1 \%$. Los símbolos indican periodos de características físicas contrastadas en la columna de agua: períodos de estratificación por encima de la termoclina (cuadrados); periodos de estratificación por debajo de la termoclina (cuadrados rellenos); período inicial bajo el hielo durante diciembre de 1996 (círculos) y antes de formarse, diciembre de 1997 (triángulos). 
surface layers below the ice. The lack of pigment increase per cell with decreasing light regime in the ice-free period can be interpreted as a consequence of the growth limitation by nutrient availability, rather than light (Geider et al., 1997). In contrast, the populations at the beginning of the ice-covered period did show a photoacclimation response in the form of an increase in pigment content per biovolume because these populations were growing in nutrient-replete conditions during the prior overturn mixing (Catalan, 1992).

\section{UV radiation}

Despite a high frequency of cloudy days and the presence of an ice cover during winter, organisms in high mountain lakes may be exposed to high ultraviolet radiation (UVR) doses (Sommaruga, 2001), because of its natural increase with elevation. In addition, there is a larger relative increase of the most damaging part, UV-B (Sommaruga \& Psenner, 1997). High mountain lakes are usually highly transparent to UVR, yielding low attenuation of short wavelength (Fig. 5). The high transparency is due to low dissolved organic carbon (DOC) concentration (Morris et al., 1995) because of decreasing soil development, vegetation cover and catchment size with altitude (Sommaruga et al., 1999). As a consequence of the low DOC concentrations, its composition and optical properties as well as the algal abundance become essential parameters to understand UV attenuation in high mountain lakes (Laurion et al., 2000). A general accepted view of the solar UVR effects on live in high mountain lakes is still missing because of different studies evidenced controversial results. For instance, Carrillo et al. (2002) showed a significant inhibition of primary and bacterial production by UVR in shortterm experiments, whereas Halac et al. (1997) found no UVR effects on phytoplankton growth rate and on species composition in a long-term enclosure experiment. The solar spectral region considered (UVA and/or UVB), the selected time scale, the biological process measured, the abiotic and biotic factors interaction, the specific target and their different sensitivity to UVA and

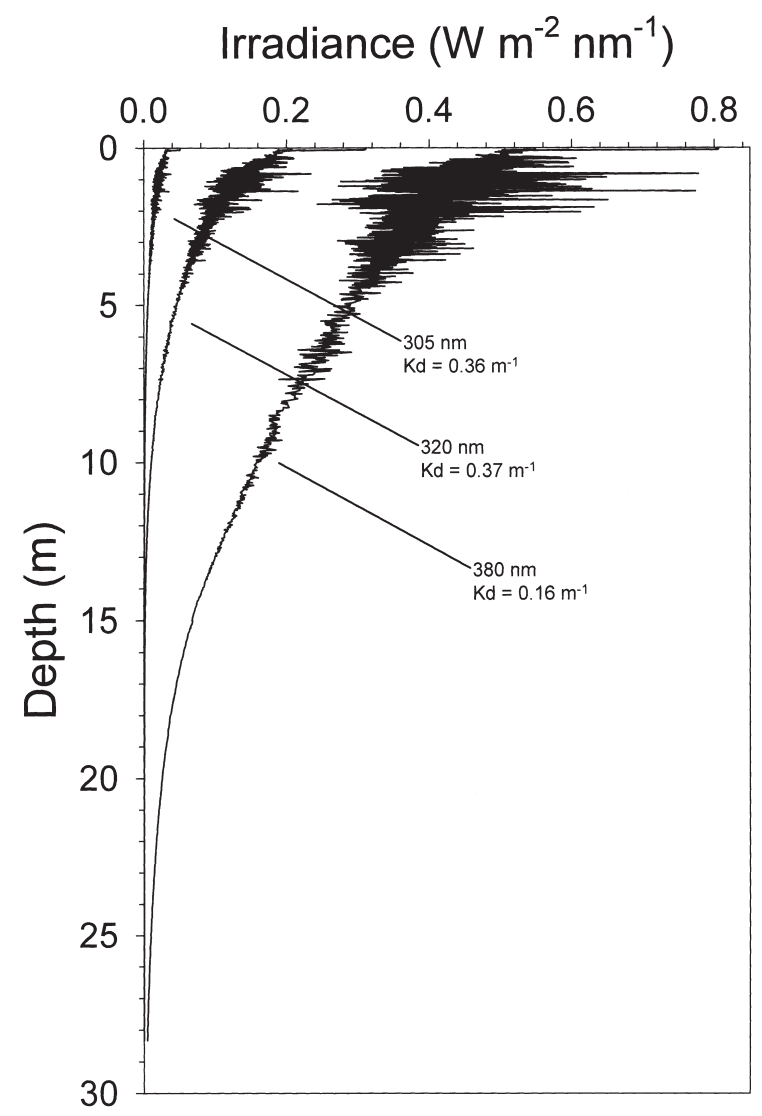

Figure 5. Depth changes in UV irradiance at 305, 320, and $380 \mathrm{~nm}$ in Lake Redon measured on 22 July 2005 (13:00 h) with a radiometer BIC 2104. The attenuation coefficients (Kd) are also indicated. Cambios en profundidad de radiación UV a 305, 320 y $380 \mathrm{~nm}$ en el Lago Redó medidos el 22 de julio de 2005 (13:00 h) con un radiómetro BIC 2104. Los coeficientes de atenuación $(K d)$ también se indican.

UVB linked to photoprotection and photoreparation mechanisms, could account for such controversy. Different mechanisms to avoid, protect or recover from UVR damage have been described in organisms living in high mountain lakes: the synthesis of compounds that directly or indirectly absorb UV photons, such as melanin, carotenoids, scytonemin, and mycosporine-like amino acids (MAAs) (Sommaruga, 2001); efficient DNA-photorepair mechanisms (Medina-Sánchez et al., 2002); behavioural strategies, for instance, daily migrations (Felip \& Medina-Sánchez, in prep.); metabolic strategies, as enhanced photosynthetic carbon excretion (Carrillo et al., 2002; Medina-Sánchez et al., 2006), or mixotrophic feeding (Medina-Sánchez et al., 2004). 


\section{Long winters: opportunity for alternative habitats}

\section{Ice and snow cover dynamics}

During winter an ice and snow cover forms in most high mountain lakes, which may last for more than half a year at mid-latitude, depending on altitude. When the lake water freezes at the beginning of the winter, the ice formed is very clear and light can penetrate deep into the lake. Because of the optical effect, this ice is known as black ice. On top of it, snow accumulates, its weight pushes the whole cover down and lake water floods the snow layer until a hydrostatic equilibrium is reached, forming a slush layer. These slush layers may occasionally freeze, forming an opaque ice, known as white ice. New snowfalls provide new layers, and the process of flooding, slush forming and freezing may repeat several types during winter, producing a complex structure of layers of distinct nature in the ice cover (Catalan, 1989). Overall, the amount of lake water equivalent in the ice cover provided by lake water flooding is higher than the amount provided by snowfalls. The maximum thickness of the ice cover is achieved during spring (April), and then a progressive melting starts from top downwards. Large temporary shallow pools may form on top of the cover, before large cracks divide it. During the melting period, thawing in the catchment maintains a large water flow of the water through the lake and, occasionally, through some of the lake cover layers. Transformations in the physical structure of the snow and ice cover have a parallel in the changes of the chemical composition of the distinct layers (Granberg, 1985; Johannesen \& Henriksen, 1978; Tsiouris et al., 1985). During freezing salts tend to be excluded from the ice and are released to water or concentrate on the outer layers of the ice grains and crystals. During the earlier stage of melting, these outer layers melt first and most of salts are released. In a later stage, the remaining soluteimpoverished ice yields very diluted melting water. The chemical evolution of the snow cover of Lake Redon monitored during the winter
1991-92 illustrates these changes. During the formation of the black ice on the lake, salts were very efficiently exsolved from the ice, and the water right under it became more concentrated. Later on, when the snow accumulated onto the black ice sheet and the lake water intruded into the cover producing slush, two phases could be distinguished: the liquid phase (flooding water), and the solid phase (ice as both compact layers and grains). In the solid phase two clearly chemically characterized zones could be distinguished: above and below the water level. Above, the salt content was higher, basically reflecting the composition of atmospheric deposition. Below, the ice was washed out of salts, and the liquid phase was more concentrated as a result of the migration of salts from the ice. During the first stages of the cover, the liquid phase was markedly enriched by the exclusion of salts from the black ice. Later on, the concentration decreased but was still 3 to 4 -fold that of ice, maintained by the scavenged salts coming from the newly deposited snow on the lake and the catchment. This situation lasted until the ablation period. In this moment, diluted melting water from the catchment circulated through the ice cover massively. The diluted water is the result of the melting of the snow cover of the catchment, which has previously lost solutes during the season by partial melting. The quantitative changes in the solute content are also accompanied by qualitative changes. Not all ions are excluded from the ice phases at the same rate. Thus, for instance, in the ice and snow layer above the water level the ratio strong anions/base cations tended to decrease with time after the major deposition events. This indicates a relatively preferential mobilisation of anions. In the lower layers, both liquid and solid, there was an increasing trend of the strong anions/base cations ratio possibly reflecting the preferential migration of anions from the upper layer, but also the increasing volume of water coming from the snow cover of the catchment, which had elevated values of the quotient. The highest values are reached during the massive circulation of the melting water coming from the catchment. The $\mathrm{pH}$ of surface snow was con- 


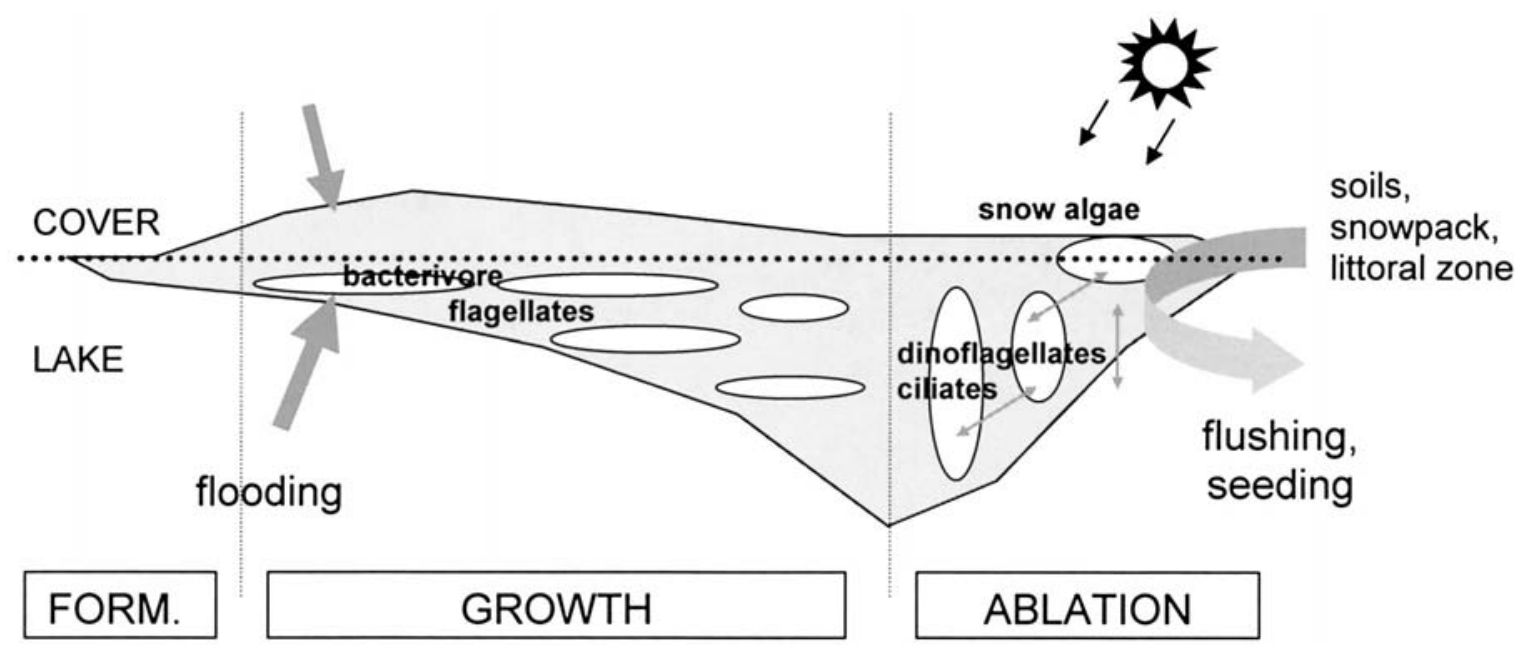

Figure 6. Summary of the main processes involved in the physico-chemical structure of the ice and snow cover and in determining changes in the microbial assemblages (modified from Felip et al., 2002). Resumen de los principales procesos involucrados en la estructura físico-química de la cubierta de hielo y nieve y en determinar cambios en la comunidad microbiana (modificado de Felip et al., 2002).

sistent with the strong anions/base cations quotient: snow with a higher percentage of anions had a lower $\mathrm{pH}$ than snow with more cations. Below the water level, the $\mathrm{pH}$ of ice was more constant. In water, the $\mathrm{pH}$ was also constant and more neutral, except for the melting period when there was a remarkable decrease.

\section{Slush microbial life}

The presence of highly active microbial communities in the slush layers of the winter cover has been described in high mountain lakes of the Pyrenees and the Alps (Felip et al., 1995). Bacteria and many taxa of autotrophic and heterotrophic flagellates and ciliates inhabit slush layers and pools produced on top of the winter cover during late spring. A detailed study in Lake Redon (Pyrenees) showed that temporal changes in microbial assemblages are strongly affected by the physical transformation of the lake cover and the snow pack in the catchment (Felip et al., 1999b). Further studies confirmed that similar changes occur in the Alps (Felip et al., 2002) and a general pattern can be established. After an initial phase, during which the ice sheet forms and the snow starts to accumulate, with little or no develop- ment of slush layers (formation period), there are two stages of microbial assemblages, which coincide with the two main phases in the physical changes of the cover, i.e. the growth and the ablation period (Fig. 6). During the growth period, broadly from approximately January to mid-April (Pyrenees) or from January to midMay (Alps) microbial assemblages of the ice and snow cover are characterized by the influence of lake water organisms. Surface lake water, which floods the cover as a result of the hydrostatic adjustment after each snowfall, acts as an inoculum for the slush layers. Potential mixotrophic (mainly chrysophytes and cryptophytes) and heterotrophic flagellated species grow and peak at different slush layers over time. Throughout the winter period of cover growth, the assemblages become poorer in terms of density and diversity, reaching minimum values at the end of this period. The growth period of the winter cover results in an increased separation of the lake from the outer world, and during this period less than $0.1 \%$ of the incident light may reach the lake water (Catalan, 1992). The winter cover growth period represents then a transition from autotrophic to heterotrophic conditions for the lake water and the deeper layers of the cover. 
During ablation, the rate of change in the species composition of the cover is higher and microbial assemblages are characterized by the vertical segregation and by the appearance of new species (dinoflagellates, i.e. Gymnodinium), some of which are typically non-planktonic (large ciliates typical of benthic sites or large red volvocales typical of snow habitats). During this time, the cover is influenced by the large amount of melting water coming from the snow pack in the catchment. The cover appears to be more dynamic and sporadically richer in organisms' density and biomass than the water column (Felip et al., 2002). Similar observations in Arctic marine ice communities showed that variability of phytoplankton distribution, species diversity and cell numbers were higher in the ice cover than in the water column (Hsiao, 1992). The use of molecular biological methods to identify bacterial populations shows that abundance of filamentous bacteria and some bacterial phylotypes clearly differs between slush layers and water column (Alfreider et al., 1996). The mutual influence between lake water and cover assemblages affects only the upper 1-2 $\mathrm{m}$ of the water column, which shows a high rate of temporal change. Microbial composition in deeper layers is poorly related to cover assemblages and temporal changes are slow.

\section{Remote localities difficult to reach}

The location of mountain lakes at high altitude and at headwaters of the river systems does not facilitate colonisation. The challenges to reach these lakes may vary from organism to organism according to the dispersal mechanisms and abilities. Comparative studies among main phylogenetically related groups are now one of our focuses of attention. Here we comment in two contrasting major groups: picoplankton and macroinvertebrates.

\section{Picoplankton distribution}

Picoplankton (i.e., cells smaller than $3 \mu \mathrm{m}$ ) is a largely unknown biological fraction in any aquatic ecosystems and mainly in high mountain lakes. The picoplankton components (both prokaryotes- Bacteria and Archaea- and eukaryotes) are difficult to distinguish by microscopy because of their small size and the lack of morphological characters. They constitute, by far, the largest reservoir of life and encompass the major part of physiological and phylogenetic diversity (Woese, 1987) but traditional microbiological approaches using well-defined culturing methods have failed to offer a convincing view on the biological structure of picoplankton because the low cultivability of microorganisms. Thus, picoplankton assemblages have been considered as a "black box" of different species with different physiologies and ecologies very difficult to tell apart. In the last decade our perception of microbial diversity has dramatically changed by retrieving ribosomal RNA genes (mostly $16 \mathrm{~S}$ rRNA and $18 \mathrm{~S}$ rRNA) from the environment, without the need to have pure cultures for examination (e.g., Casamayor et al., 2000; 2002). Although microbial diversity studies are carried out with entities that are not strictly species, these rRNA genes can be used as a proxy of microbial species composition and have allowed microbial ecologists to develop a more ecological thinking on bacterial (Bacteria and Archaea) ecology. This approach results extremely helpful to bridge the existing gap between ecologists of tall and tiny (Pedrós-Alió \& Guerrero, 1994). High mountain lakes exemplify very well remote systems that can be considered as islands within a "sea" of land difficult to reach for most of the microbes. In addition, they are also extreme environments with persistent low temperatures, low nutrient availability and high UV exposure along the year that might hold an adapted specialist microbiota. Microbes have been considered to be cosmopolitans and because of their high dispersal rates and tremendous population size they are easily transported to very distant places. If that is the case, we should find similar picoplankton assemblages in similar high mountain lakes worldwide. Certainly, high mountain lakes are a source of new and inte- 
resting microbial taxa as well as natural models to increase communication between the ecological and microbiological scientific communities. Our present studies focus in two main lines of research. In the first approach we analyse the composition of bacterial assemblages in situ by isolating the total DNA from the sample, amplifying the genes of interest (usually the genes coding for the 16S rRNA), and cloning these genes. After sequencing, a relatively unbiased picture of the microbial diversity from natural samples can be obtained. Recent advances in molecular techniques and increased communication between the ecological and microbiological scientific communities now allow us to examine patterns of bacterial richness along environmental gradients and to look for predictor variables. The available studies seem to indicate that picoplankton from high mountain lakes show a high dominance of a few bacterial taxa (Reche et al., 2005; Warnecke et al., 2005) mainly Beta-Proteobacteria and Actinobacteria (Zwart et al., 2002). Archaea have been detected in different high mountain lakes areas but within a range of $5-10 \%$ of total DAPI counts (Pernthaler et al., 1998; Medina-Sánchez et al., 2005). Since none of these freshwater archaea has been isolated in pure culture their metabolism and their role in high mountain lakes ecosystems is unknown. Pelagic prokaryotic communities in lakes contain representatives from the same major phyla as marine microbial communities but detailed sequence analyses have revealed that most phylotypes obtained from freshwater communities form distinct phylogenetic clusters that represent species that appear to be unique to freshwaters. In addition, from the study carried out in Sierra Nevada, the bacterial composition among lakes appeared to be quite heterogeneous, with a high number of site-specific phylotypes (Reche et al., 2005). We are now involved in a more complete study covering wider regions in the Pyrenees, Alps, Sierra Nevada, Patagonia, Arctic and Antarctic. The second line of thinking uses general ecologists' statistical techniques to investigate the applicability of ecological concepts to bacteria in the natural environment (Reche et al., 2005). In a recent study in high mountain lakes of Sierra Nevada (Spain), it was found a solid pattern between lake area and bacterial phylotypes richness. The bacterial richness-area relationship showed a low slope value as is common for organisms with high dispersion rates. Consequently, lake remoteness did not appear to affect the number of bacterial phylotypes found there, although the distribution of lakes influenced bacterial communities yielding similar bacterial phylotypes composition in nearby lakes.

\section{Macroinvertebrate distribution}

Macroinvertebrates inhabiting the littoral of high mountain lakes include a wide spectrum of organisms that differ greatly in their biological cycles, feeding behaviour, and dispersal strategies. In the context of mountain lakes as remote localities difficult to reach, the dispersal strategies of different macroinvertebrate groups play a critical role, especially as altitude increases and lakes become more remote. Dispersal abilities vary greatly among macroinvertebrate groups: whereas all aquatic insects have a flying adult stage, which allows them to overcome long distances, other macroinvertebrate groups such as worms, snails, and water mites do not have such flying stage and, therefore, exhibit a slow dispersal process which often needs of a transportation vector. For instance, in the case of water mites, chironomids are not only used as a feeding resource, but also as a vector for dispersal (Smith \& Oliver, 1976). In the case of oligochaetes, dispersal could be achieved passively or actively through phreatic water, artificial channels, and flooded land, or just passively by air (cysts and cocoons) under moist and cool weather (Timm, 1980). Similarly, adult movement and passive transportation of coccoons are possible within triclads (Young \& Reynoldson, 1999). From a survey of 82 lakes from the Pyrenees (which were selected to be representative of the whole altitudinal range), we observed that among the main groups of macroinvertebrates found (i.e. those present in at least $10 \%$ of 
Table 1. Main groups of macroinvertebrates inhabiting the littoral zone of mountain lakes from the Pyrenees. $\mathrm{S}=$ slow dispersal, $\mathrm{F}=$ relatively fast dispersal, $*=$ only one species found within the family, $\mathrm{f}=$ frequency of appearance in a survey of 82 altitudinally representative lakes, n.s. = not significant (two-tailed Student-t test). Principales grupos de macroinvertebrados propios del litoral de los lagos de montaña de los Pirineos. $S=$ dispersión lenta, $F=$ dispersión relativamente rápida, * = familia con sólo una especie, $f=$ frecuencia de aparición en un muestreo de 82 lagos representativos de la variación altitudinal, n.s. = no significativo (test $t$-Student de dos colas).

\begin{tabular}{|c|c|c|c|}
\hline Family / Subfamily & $f$ & $\begin{array}{l}\text { Relation } \\
\text { to altitude }\end{array}$ & $\begin{array}{l}\text { Most frequent genera within the family or subfamily } \\
\text { in Pyrenean lakes }\end{array}$ \\
\hline Hydridae (S) & 0.20 & Negative & Hydra \\
\hline Planariidae (S) & 0.12 & Positive & Phagocatta \\
\hline Lumbriculidae (S) & 0.72 & n.s. & Lumbriculus, Stylodrilus \\
\hline Naididae (S) & 0.83 & Negative & Chaetogaster, Nais, Specaria, Vejdovskyella \\
\hline Enchytraeidae (S) & 0.89 & n.s. & Cernosvitoviella, Cognettia \\
\hline Glossiphoniidae (S) & 0.12 & Negative & Helobdella \\
\hline Ancylidae $(S) *$ & 0.18 & n.s. & Ancylus \\
\hline Lymnaeidae $(S)$ * & 0.26 & Negative & Lymnaea \\
\hline Sphaeriidae (S) & 0.50 & Negative & Pisidium \\
\hline Lebertiidae (S) & 0.41 & n.s. & Lebertia \\
\hline Hygrobatidae (S) * & 0.17 & n.s. & Hygrobates \\
\hline Pionidae (S) & 0.10 & n.s. & Piona \\
\hline Baetidae (F) & 0.23 & n.s. & Cloëon \\
\hline Corixidae (F) & 0.10 & n.s. & Arctocorisa \\
\hline Sialidae $(F) *$ & 0.56 & Negative & Sialis \\
\hline Dytiscidae $(F)$ & 0.49 & n.s. & Hydroporus, Agabus \\
\hline Chironomidae (sF. Tanypodinae) $(F)$ & 0.94 & n.s. & Ablabesmyia, Macropelopia, Procladius, Zavrelimyia \\
\hline Chironomidae (sF. Orthocladiinae) (F) & 0.98 & n.s. & Corynoneura, Heterotrissocladius, Psectrocladius \\
\hline Chironomidae (sF. Chironominae) (F) & 0.96 & n.s. & Micropsectra, Paratanytarsus, Tanytarsus \\
\hline Polycentropodidae (F) & 0.52 & n.s. & Plectrocnemia, Polycentropus \\
\hline Limnephilidae $(F)$ & 0.43 & n.s. & Annitella, Drusus \\
\hline Leptoceridae $(F)$ & 0.16 & Negative & Mystacides \\
\hline
\end{tabular}

lakes) negative relations to altitude, and therefore to remoteness, were quite frequent (Table 1). However, this is not likely to be purely consequence of the difficulty to reach high altitude lakes. Low altitude lakes are warmer and generally more productive, and often hold macrophytes (Gacia et al., 1994), enhancing habitat heterogeneity and refugee against predation (e.g. Gilinsky, 1984). In this sense, high altitude lakes could just be more unfavourable environments, which are only preferred by cold-stenothermal groups. In fact, the distributions of nonflying dispersers are often unaffected by altitude, even within those groups having only one single species (i.e. the snail Ancylus fluviatilis in Ancylidae, and the water mite Hygrobates foreli in Hygrobatidae). Water mites (i.e. Hydrachnidia) such as Hygrobatidae, provide a good example of the efficiency of the passive dispersal process. With the same survey of lakes (but only considering those lakes where water mites were present), the species richness for any given number of lakes was obtained by sampled-based rarefaction (Gotelli \& Colwell, 2001) (Fig. 7). Then, it was plotted the hypothetical accumulation of richness that would be observed if lakes were arranged by increasing availability of chironomids (which serve both as a feeding resource and as a vector of transportation for water mites), and also by increasing availability of oligochaetes and nematodes (which could similarly serve as a food resource, but not as a vector of transportation). The number of water mite species increased faster in the 'chironomid-based' accumulation curve than in the other two cases, and differed significantly from what it could be expected by chance. This result suggests that the passive dispersal process could still contribute to the maintenance of local diversity in high mountain lakes. 


\section{CATCHMENT LAKE CONDITIONING}

\section{Rock, soil and lake water chemistry}

Multivariate statistical analysis of data on water chemistry of alpine lakes (Camarero et al., 1995) reveals that the main sources of variability are related to catchment lithological composition, amount and biological activity of soils in the catchment, and atmospheric deposition of both natural (sea salts) and anthropogenic (N and $\mathrm{S}$ compounds) solutes. Lithological composition is the feature determining the largest differences in chemistry (Catalan et al., 1993) as a consequence of weathering of rocks of different mineralogical and chemical composition. The main groups of rocks found in the Pyrenees are plutonic rocks (granites and granodiorites), sedimentary limestones, metamorphic slates and schists, detrital sandstones, and, more scarcely, some volcanic rocks. Differences between lakes lying on the main types of bedrock are clear, as it could be expected. More remarkable is the variability between granodiorite batholiths of similar mineral composition, as shown in Table 2 for lakes in the southern slope of Central and Eastern Pyrenees. The largest chemical differences are found in the base cations content, mainly $\mathrm{Ca}^{2+}$, and the alkalinity. There is a close relationship between alkalinity and the

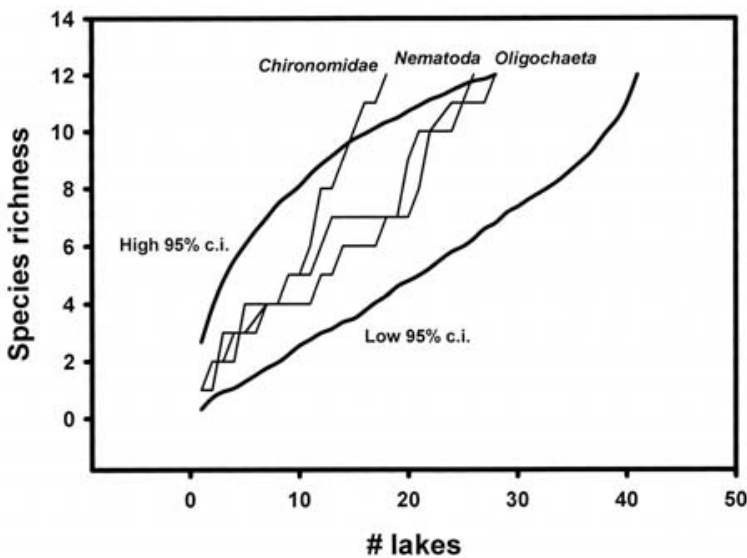

Figure 7. Sample-based rarefaction curves (95\% confidence intervals) for water mite species (i.e. Hydrachnidia) across the survey of lakes from the Pyrenees, only lakes where water mites were present were considered, $n=41$. Species richness accumulation was also plotted for lakes arranged by increasing number of Chironomidae, Oligochaeta and Nematoda, respectively. Curvas de rarefacción basadas en muestras (intervalos de confianza del $95 \%$ para especies de ácaros (i.e. Hydrachnidia) a lo largo de un muestreo de lagos pirenaicos, sólo los lagos con presencia de ácaros fueron considerados, $n=41$. Acumulación de riqueza de especies para los lagos ordenados en número creciente de Chironomidae, Oligochaeta y Nematoda, respectivamente.

percentage of the different rocks found in the catchment that allows the prediction of the range of alkalinity for a lake, based only on the lithology, with good accuracy and confidence. For the strong anions, usually $\mathrm{SO}_{4}{ }^{2-}$ dominates the ion balance, because it can be supplied in

Table 2. Mean values of chemical variables for lakes on different bedrock. Valores medios de variables químicas para lagos en distintos sustratos rocosos.

\begin{tabular}{|c|c|c|c|c|c|c|c|c|}
\hline & & \multicolumn{4}{|c|}{ Granidoritic batholiths } & \multirow{2}{*}{$\begin{array}{l}\text { Cambro- } \\
\text { Ordovician } \\
\text { schists }\end{array}$} & \multirow[b]{2}{*}{$\begin{array}{l}\text { Devonian } \\
\text { limestones }\end{array}$} & \multirow[b]{2}{*}{$\begin{array}{c}\text { Silurian } \\
\text { slates }\end{array}$} \\
\hline & & Maladeta & Bassiers & Marimanha & $\begin{array}{l}\text { Montlluís } \\
\text { Andorra }\end{array}$ & & & \\
\hline Conductivity & $\mu \mathrm{S} \mathrm{cm}-1$ & 21.6 & 4.7 & 20.2 & 27.7 & 11.1 & 44.2 & 40.9 \\
\hline $\mathrm{pH}$ & & 7.40 & 5.80 & 6.95 & 6.98 & 6.17 & 7.24 & 4.50 \\
\hline Alkalinity & $\mu$ eq $1^{-1}$ & 155 & 31 & 140 & 249 & 42 & 333 & $<0$ \\
\hline $\mathrm{SO}_{4}^{2-}$ & $\mu$ eq $1^{-1}$ & 38 & 21 & 26 & 47 & 47 & 53 & 236 \\
\hline $\mathrm{Cl}^{-}$ & $\mu$ eq $1^{-1}$ & 11 & 7 & 11 & 13 & 10 & 22 & 11 \\
\hline $\mathrm{NO}_{3}^{-}$ & $\mu$ eq $1^{-1}$ & 8.6 & 3.7 & 10.5 & 15.6 & 14.9 & 10.9 & 5.3 \\
\hline $\mathrm{NO}_{2}^{-}$ & $\mu$ eq $1^{-1}$ & 0.11 & 0.06 & 0.14 & 0.15 & 0.09 & 0.21 & 0.03 \\
\hline $\mathrm{NH}_{4}^{+}$ & $\mu$ eq $1^{-1}$ & 1.4 & 0.9 & 1.6 & 1.6 & 1.3 & 3.2 & 2.3 \\
\hline $\mathrm{Ca}^{2+}$ & $\mu$ eq $1^{-1}$ & 168 & 21 & 150 & 206 & 55 & 353 & 44 \\
\hline $\mathrm{Mg}^{2+}$ & $\mu$ eq $1^{-1}$ & 10 & 5 & 13 & 27 & 11 & 31 & 28 \\
\hline $\mathrm{Na}^{+}$ & $\mu$ eq $1^{-1}$ & 23 & 11 & 29 & 42 & 20 & 23 & 28 \\
\hline $\mathrm{K}^{+}$ & $\mu$ eq $1^{-1}$ & 7 & 2 & 6 & 9 & 5 & 19 & 3 \\
\hline Total P & $\mu \mathrm{mol} \mathrm{l} \mathrm{l}^{-1}$ & 0.29 & 0.18 & 0.27 & 0.40 & 0.15 & 1.47 & 0.14 \\
\hline
\end{tabular}



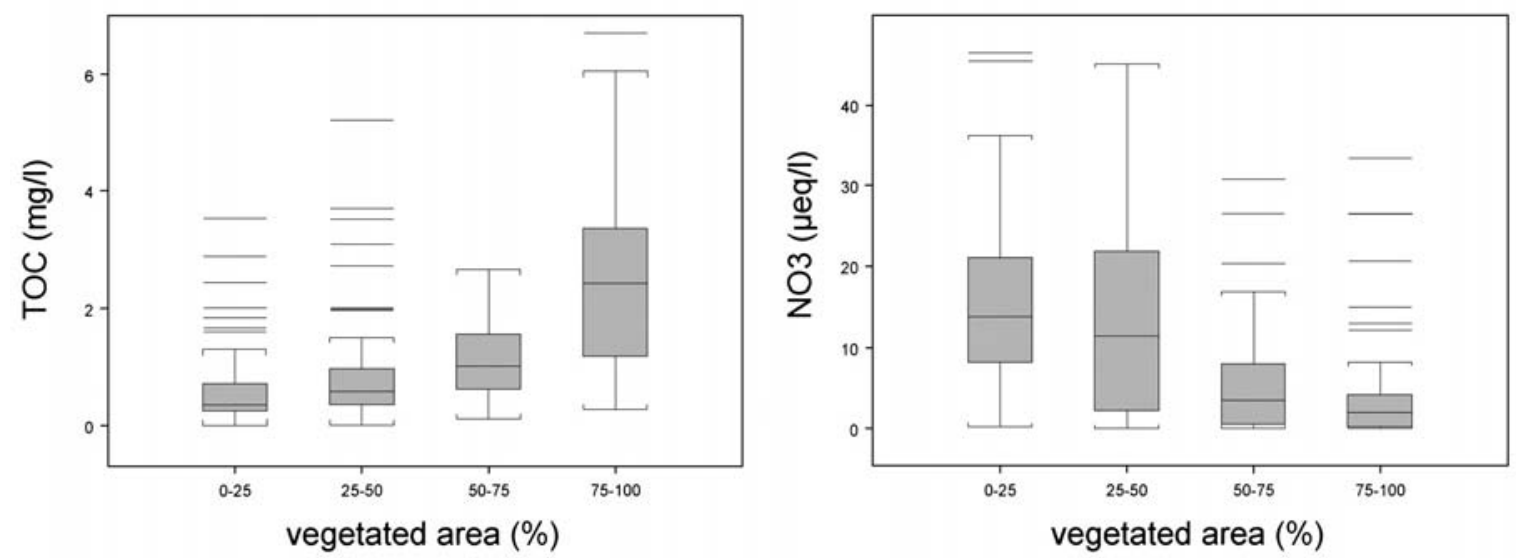

Figure 8. Variability of total organic carbon and nitrate concentrations among catchments with a distinct degree of vegetation. Variabilidad de carbono orgánico total y nitratos en cuencas con distinto grado de vegetación.

large amounts by some rocks. Lakes with a concentration of $\mathrm{SO}_{4}{ }^{2-}$ less than c. $50 \mu \mathrm{eq} \mathrm{1}^{-1}$ have no significant geological supply of sulphur, being most of it of atmospheric origin. Above this limit, rock-derived $\mathrm{SO}_{4}^{2-}$ becomes often the major fraction, and the $\mathrm{SO}_{4}{ }^{2-}$ concentration can also be reasonably predicted on the basis of the percentual composition of rocks in the catchment. Dissolved Si has an almost exclusively geological origin. There is a significant relationship between concentration of dissolved $\mathrm{Si}$ and some features of the catchments as the percentage of plutonic rocks, the percentage of glacial deposits, the altitude of the lake (negatively correlated), and the catchment area. The proportion of siliceous plutonic rocks has an obvious weight on the $\mathrm{Si}$ found in the lakes. The other variables can be interpreted as indicators of conditions that favour their weathering: glacial deposits are areas of fragmented rocks that increase the surface exposed to weathering; larger catchment areas mean also more surface weathered, and the negative correlation with altitude may have the same meaning, in the sense that lower lakes lie generally in larger catchments; another possible effect of altitude is higher temperatures at lower altitude enhancing the weathering reactions.

The soils found in the catchment play also an important role in determining the chemistry of the lakes. Regarding physico-chemical proces- ses, soils act as a cation exchange complex storing or releasing base cations previously weathered from rocks or atmospherically deposited, depending on the environmental conditions (e. g. quantity and chemistry of precipitation, temperature). From this point of view, the key soil parameters are their cation exchange capacity (CEC) and the percentage of base saturation (BS \%). Both parameters are related to some features of the catchments. Results from a survey of 13 catchments (35 soil pits sampled), selected in order to get a representation of all main lithologies and lake water chemistries over the Pyrenean range, showed that CEC can be predicted on the basis of the total organic carbon (TOC) of the soil and a lithological parameter (Camarero, unpublished data). To compute the lithological parameter, the different kind of rocks were ranked from less to more solubility as indicator of the capacity of supplying cations, and the parameter was then computed as an average of the ranking, weighted by the proportion of each type of rocks in the catchment. TOC can be in turn predicted based on percentage of the catchment covered by soil, the orientation of the valley (deviation from $\mathrm{N}$ ), the amount of precipitation, and the percentage of relatively soluble plutonic rocks and carbonated rocks. The BS \% was correlated with the lithological parameter and the orientation of the valley. In this context, orientation of the valley may be interpreted as a 
surrogate for insolation and temperature. Predictions of CEC based on the catchment characteristics are less accurate than those of BS \%, but sufficient nonetheless for biogeochemical modelling of lake water chemistry. Soils hold also a biological activity that influences the chemistry of water. Related to this, it has been found a positive correlation between the percentage of the catchment covered by soil and dissolved organic carbon (DOC), dissolved organic nitrogen (DON), and total phosphorus (TP), whereas this correlation is negative with $\mathrm{NO}_{3}^{-}$(Fig. 8). This inverse relationship may be the result of independent processes active in the catchment related to amount of soil and the water residence time in it (larger DOC production and larger $\mathrm{NO}_{3}{ }^{-}$consumption with more soil determining a longer residence time; Kopacek et al., 2005), or the result of direct interaction between $\mathrm{C}$ and $\mathrm{N}$. For example, $\mathrm{NO}_{3}{ }^{-}$consumption by denitrification in the catchment may be limited by DOC availability (Goodale et al., 2005).

\section{Long term changes in lake productivity}

At long time scales (i.e. from a few decades to millennia) the key element controlling primary production in mountain lakes is the coupling of lake dynamics with the catchment biogeochemistry. Phosphorus is an scarce element at those altitudes, therefore, it is efficiently retained by vegetation. A reconstruction of the productivity changes throughout the Holocene in Lake Redon showed that there was an initial phase of a few thousand years of high productivity, but afterwards the productivity decreased and stabilised during more than six thousand years, with slight fluctuations although there were relevant oscillations in climate. Only since 1500 years BP onwards, the lake productivity increased again in parallel to an increase in sedimentation rates of detrital material. This increase has been interpreted as soil erosion after the onset of sheep grazing activity (Buchaca, 2005), despite that it is restricted to a few days per year. The lake is still highly oligotrophic nowadays, but the study shows how sensitive those ultraoligotrophic lakes are to a small increase in phospho- rus loading and, on the other hand, how efficient in retaining phosphorus is the vegetation-soil complex, when it is not mechanically affected.

\section{WITNESSES OF ENVIRONMENTAL CHANGES}

\section{Recent direct anthropic alterations}

Despite their remoteness, high mountain lakes have been affected by some direct anthropic alterations. Historically was deforestation and erosion related to pasturing activities was relatively low, except in the lowest lakes located below treeline. In recent times, direct alterations are related to hydropower exploitations (Catalan et al., 1997) and lake stocking with fish (Miró \& Ventura, 2004). Abrupt changes in water level, as a result of impounding, may affect all the littoral biota and particularly the survival of macrophyte populations (Gacia \& Ballesteros, 1996). The introduction of fish, due to their establishment as top predators may affect and, eventually, suppress some species typical of these high altitude sites (Bradford et al., 1998; Knapp et al., 2001). Fish were not able to reach naturally most of these high altitude lakes, because of the existence of steep slopes and subterranean parts in the streams flowing from the lakes. Therefore, the actual presence of fish in most lakes can only be attributed to artificial stocking. In order to identify the origin, the historical utilisation, and the present status of the fish species distribution in the lakes of the Aigüestortes i Estany de Sant Maurici National Park, we performed an extensive bibliographic search in historical archives and personal interviews to local elderly people. The National Park, situated in the Central Pyrenees, has approximately 200 lakes larger than 0.5 ha, which represents a $20 \%$ of all the lakes of the Pyrenees. The first documented records of fish introductions in the lakes of the National Park have been dated to the end of the sixteenth century. However, in other Pyrenean areas there have been very old citations going back to the beginning of the fifteenth century -1423 
which refers to fishing rights of a lake. There is a scarcity of direct written evidences of fish introductions to the lakes of the National Park during the middle Ages, but these showed that fish introductions in the Pyrenean lakes dated back at least from those times (Valls-Taberner, 1988). These initial introductions were done with individuals of autochthonous brown trout (Salmo trutta), which were fished from nearby streams and were restricted to the lowest lakes due to their easiest access. The main purpose of these initial introductions was related with alimentary requirements of the local communities, but also they were used as a complementary economic resource. This traditional use drastically changed during the second half of the last century (Fig. 9a), when widespread introductions related with leisure fishing activities were recorded. Introductions consisted of allochthonous stocks of brown trout but also of other exotic salmonids such as rainbow trout (Oncorhynchus mykiss), brook trout (Salvelinus fontinalis) and the cyprinid European minnow (Phoxinus phoxinus). In some cases, these introductions were financed by the hydroelectrical companies in order to compensate local communities for the potential loss of fishing resources associated with the hydroelectrical activity and implied a drastic change in the stocking policy. As a result, only a $28 \%$ of the lakes have

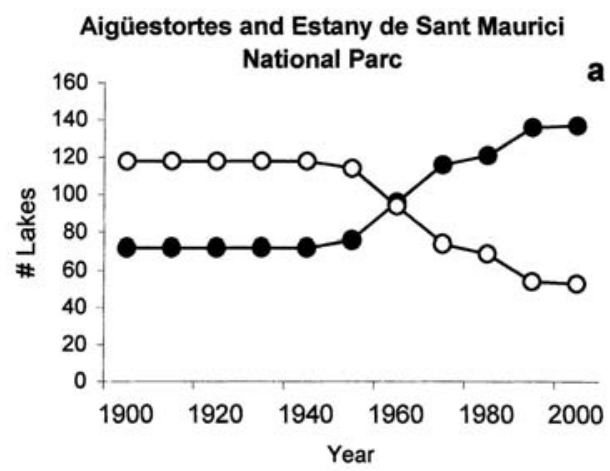

remained fish-less nowadays in the National Park. This percentage is even more striking for some lake-size categories (Fig. 9b), since most of the lakes above 3 ha in the National Park have suffered fish introductions.

\section{Long distance pollution transport and toxification of nature}

Our society has a tendency to increase the use of natural resources and to externalise wastes. The concern about the changes that this behaviour may originate in nature and to our own place in it did not grow in parallel with the timing and magnitude of those changes. The closer the systems affected were, the earlier was the recognition of the problems. This is well illustrated by eutrophication and acidification (Psenner and Catalan 1994). Measures against eutrophication started with a delay of about 10 years after the onset of ecosystem decline. However, it took about one century to implement sulphur emission reductions, since acidification started. If we consider heavy metal pollution, we see that the delay in reacting has even taken longer. Nowadays, in addition to those pollutants, which are merely natural wastes, nature faces also an increasing loading of new substances, since industrialisation brought also a revolution in organic chemistry, which leads to a global

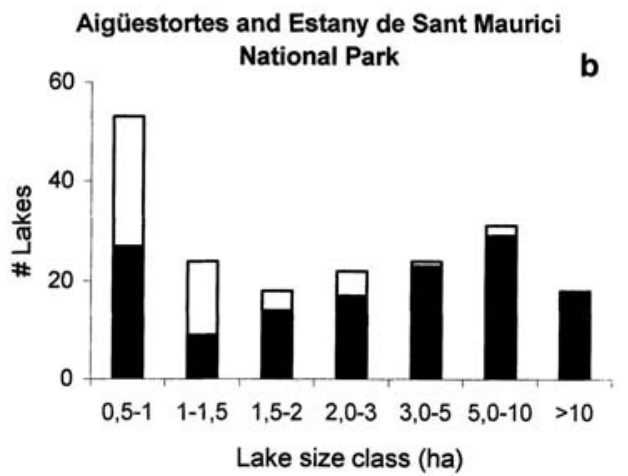

Figure 9. Non-native fish introduction history (a) and present status (b) in the lakes larger than 0.5 ha of Aigüestortes i Estany de Sant Maurici National Parc (Central Pyrenees). Empty circles and bars stand for lakes without fish and filled circles or bars stand for lakes where non-native fish has been introduced (salmonids only in a, and all fish groups in b). Modified from Miró and Ventura (2004). Registro histórico de la introducción de peces no nativos (a) y su estado presente (b) en los lagos de más de 0.5 ha en el Parque Nacional de Aigüestortes i Estany de Sant Maurici (Pirineos Centrales). Los círculos y barras en blanco indican lagos sin peces y los círculos y barras negros indican lagos donde peces no nativos se han introducido (sólo salmónidos en a, y para todos los grupos de peces en b). Modificado de Miró \& Ventura (2004). 


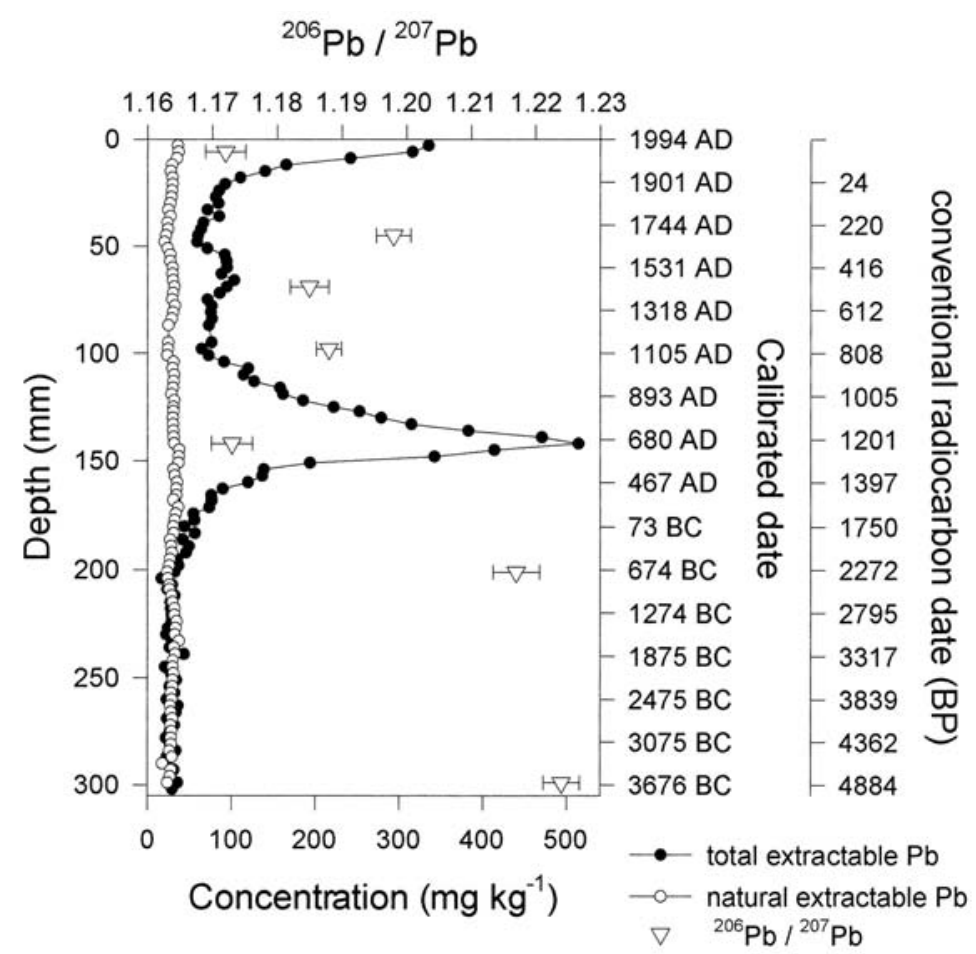

Figure 10. Total extractable and catchment-originated (natural) lead (as estimated from $\mathrm{Al}$ concentrations) and the ${ }^{206} \mathrm{~Pb} /{ }^{207} \mathrm{~Pb}$ ratio plotted against the sediment depth and time scales obtained by ${ }^{210} \mathrm{~Pb}$ and ${ }^{14} \mathrm{C}$ dating in sediments of Lake Redon (Modified from Camarero et al., 1998). Plomo total extractable y plomo originado en la cuenca (estimado a partir de la concentraciones de aluminio) y cociente ${ }^{206} \mathrm{~Pb} / 207 \mathrm{~Pb}$ con relación a escalas de tiempo y profundidad en el sedimento para el lago Redon (Modificado de Camarero et al., 1998).

toxification of nature. Remote ecosystems are the appropriate places to study the magnitude and eventual consequences of this persistent spreading of toxicants. In that sense, high mountain lakes throughout Europe have been studied in relation to acidifying agents, metals and persistent organic pollutants.

\section{Heavy metal atmospheric pollution}

The oldest long-range atmospheric pollution was that of heavy metals. The term 'heavy metal' is commonly used in environmental issues in a wide sense and it includes metalloids such as arsenic (As) and selenium (Se), because of their similar contaminant origin and toxicity. The dispersal of heavy metals into the environment has caused great concern relatively in recent times. This concern was mainly due to the large amounts of lead $(\mathrm{Pb})$ emitted from leaded gasoline in internal combustion engines, and which also warned about other heavy metals that have been identified as diffuse urban and industrial pollutants (Nriagu, 1996; Van de Velde et al., 2000a,b). However, the study of paleorecords has shown that long-range metal pollution is an old issue. Regarding the Pyrenees, lake sediments revealed heavy metal pollution since the onset of intensive mining and smelting in old Greek and Roman times (Camarero et al., 1998; Aries, 2001). In a sediment core from Lake Redon a surface peak of lead concentration that was c. 10 times higher than the background level was found (Fig. 10). This peak is attributed to the mining activities in the area since the beginning of this century, on the basis of the similarity between the isotopic composition of lead in the sediments and lead in the ores from the mines. Although lead pollution due to the combustion of gasoline was expected to be present, no evidence could be deduced from the lead isotope ratios of sediment due to the masking effect of lead from mines. A second peak appea- 
Table 3. Heavy metals content of pre-industrial lake sediments (this study) and granites (Arranz, 1991) from the Maladeta batholith, in the Central Pyrenees. Both absolute concentration and concentration normalised to Ti are shown. Values are the median and the range of the measurements in 19 rock samples and 8 lakes. Contenido en metales pesados en sedimentos lacustres pre-industriales (este estudio) y granitos (Arranz 1991) del batolito de la Maladeta en los Pirineos Centrales. Se indican las concentraciones absolutas y las normalizadas con relación al Ti. Los valores corresponden a la mediana y rango para medidas en 19 muestras de rocas y 8 de lagos.

\begin{tabular}{|c|c|c|c|c|}
\hline & \multicolumn{2}{|c|}{ concentration (ppm) } & \multicolumn{2}{|c|}{ normalized to $\mathrm{Ti}(\%)$} \\
\hline & rock & sediments & rock & sediments \\
\hline $\mathbf{T i}$ & $3117(300-6235)$ & $2224(1024-2967)$ & & \\
\hline $\mathbf{P b}$ & $2(<2-61)$ & $51(25-86)$ & $1.2(<0.1-203.5)$ & $24.5(10.6-35.8)$ \\
\hline $\mathbf{Z n}$ & $62(5-113)$ & $102(63-160)$ & $18.6(7.1-43.6)$ & $54.8(22.6-75.0)$ \\
\hline $\mathbf{C u}$ & $2.2(1.4-47.2)$ & $19.2(8.6-30.4)$ & $0.9(0.4-7.6)$ & $10.1(2.9-25.8)$ \\
\hline Hg & $\mathbf{0 . 0 0 8}(<0.005-0.014)$ & $\mathbf{0 . 0 6 7}(<0.010-1.041)$ & $\mathbf{0 . 0 0 2}(<0.002-0.030)$ & $\mathbf{0 . 0 2 7}(<0.002-1.016)$ \\
\hline As & $1.6(0.2-15.0)$ & $47.8(8.4-827.8)$ & $0.4(<0.1-14.5)$ & $18.6(3.3-45.8)$ \\
\hline Se & $<0.5$ & $2.1(<1.0-3.5)$ & $<0.2$ & $1.0(<0.5-2.6)$ \\
\hline
\end{tabular}

red in a deeper layer, with a maximum lead concentration of ca. 17-fold higher than the background level. The date of this peak is ca. $658 \mathrm{AD}$. Coincident isotopic signatures revealed that lead in both peaks must have the same origin. Nondocumented mining and smelting at a relative large scale should have then taken place in the surrounding area during post-Roman times. The rise of anthropogenic lead in sediments started around $670 \mathrm{BC}$, in good agreement with the accepted chronologies for lead pollution at a large European scale (Shotyk et al., 1998).

The comparison of the concentration of heavy metals in contemporary and pre-industrial sediments obtained from sediment cores of a number of lakes across the Pyrenees allows to assess the present day status of regional pollution (Camarero, 2003). The analyses showed that the concentration of trace metals and metalloids is significantly high in the modern sediments of these relative remote, pristine lakes, comparable to those found in moderately polluted sediments. Arsenic presents remarkably high concentrations in the Pyrenees. The sedimentary processes in these lakes, given their particular characteristics (slow sedimentation rates, rich organic content, small particle size), tend to concentrate metals in their sediments. This results in a natural enrichment in heavy metals (Table 3) compared to the source rocks (Arranz, 1991). In addition to this natural enrichment, heavy metal concentrations are further enhanced in contemporary sediments by atmospheric pollution. Overall, more than $75 \%$ of lakes showed enrichment factors (EF) for most metals above 1.5. EF being calculated as the ratio between metal concentration in contemporary and pre-industrial sediments after normalisation by titanium (Ti). The correlations among heavy metals in the surface sediments were stronger than for pre-industrial sediments, evidencing their common origin as pollutants in contemporary sediments, by opposition to lower correlations in pre-industrial sediments. Maps of the EF's show that Central and Eastern Pyrenees clearly present higher pollution levels than the Western part (Fig. 11). One current line of research in the group is the study of the deposition, mobility and redistribution of heavy metals in high mountain catchments and the aquatic ecosystems. Heavy metals fluxes to (atmospheric deposition) and within (transfer from the land to the lakes) catchments, and their inventories in the different biotic (terrestrial vegetation and aquatic food webs) and abiotic (rocks, soils and lake sediments) ecosystem compartments are being quantified and modelled at several sites in the Pyrenees, as well as in other European mountain ranges (Tatras and Tyrolean Alps) for comparison. The study sites are disposed in an altitudinal gradient encompassing gradients of temperature and precipitation. This experimental set-up allows us to test the effects of different climatic regimes on the heavy metal biogeochemical cycling, and to assess the possible impacts of climate change. 


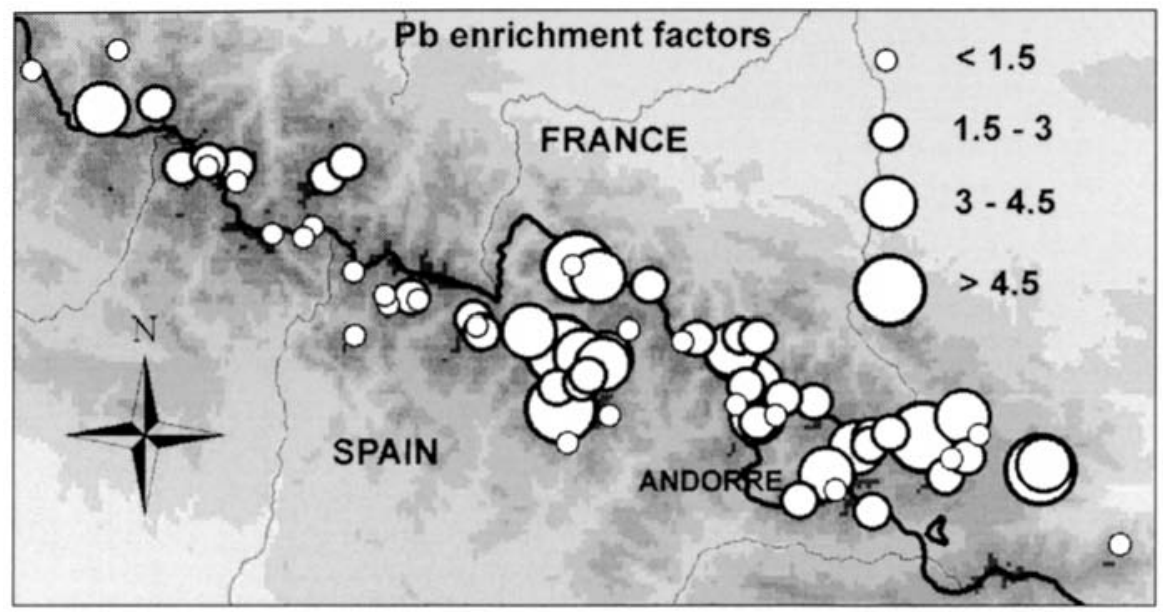

Figure 11. Geographic distribution of the enrichment factor for lead over the Pyrenees. Distribución geográfica del factor de enriquecimiento en plomo a lo largo de los Pirineos.

\section{Acidification}

Most of the lakes in the Pyrenees are sensitive to acidification, because they lie on crystalline bedrocks of low solubility producing waters of a poor acid buffering capacity (Fig. 12). But atmospheric deposition in the Pyrenees has not in general an acidic character. The levels of the acid pollutants $\mathrm{NO}_{3}{ }^{-}$and $\mathrm{SO}_{4}{ }^{2-}$ are in the same range than those in other European mountain regions receiving more acidic precipitation; however, the deposition of base cations in the Pyrenees is higher and neutralises the acid contributions (Camarero \& Catalan, 1993; The MOLAR chemistry group, 1999). The wet air masses originating precipitation over the Central Pyrenees come in about equal amounts from two main directions: NW (Atlantic) and SE (Mediterranean). Precipitation coming from the Mediterranean tends to be richer in base cations, whereas precipitation from the Atlantic has a stronger marine influence and carries more acidic $\mathrm{S}$ and $\mathrm{N}$ compounds (Camarero \& Catalan, 1993; 1996). Thus, dust from the Iberian Peninsula and Sahara seems to be an important source of base cations in the Pyrenees that neutralises the acidifying effect of the pollutants emitted. In consonance with the non-acidic character of mean deposition, the Pyrenean lakes do not present symptoms of damage caused by acidification (Catalan et al., 1993). Yet, despite the inputs of base cations, chemical acidification as a result of pollution has presumably taken place. Very sensitive-to-acidification lakes (those with $\mathrm{pH}$ between 5.5 and 6.5, and alkalinity less than $50 \mu$ eq $1^{-1}$ ) are estimated to be ca. $15-20 \%$ of all lakes in the Pyrenees. Modelling of the regional alkalinity of the lakes, taken into account the estimated changes in acid loading over time, indicates that by 1987 an average loss of alkalinity of $35 \mu \mathrm{eq} 1^{-1}$ had occurred since 1900 (Camarero \& Catalan, 1998). This has had little effect in terms of a real acidification of lakes, but the buffering capacity of soils (i.e. their exchangeable cation pool) has been significantly depleted, and replenishment is taking place at a slow rate (Wright et al., 2005), enhancing the sensitivity of the catchments. At the present day in the Pyrenees, and despite the reduction in the sulphur oxides emissions to the atmosphere and subsequent deposition (Mosello et al., 2002), the acid deposition still exceeds the critical load in ca. $10-12 \%$ of lakes according to models (Curtis et al., 2005). Nitrogen deposition is more important than sulphur deposition in causing exceedance for most sites, highlighting the need to incorporate nitrogen processes in critical loads models for this region. Other drivers may also affect the processes determining the acid-base balance in the Pyrenean lakes, as for instance weathering rates enhanced by climate warming (Camarero et al., 2004). 


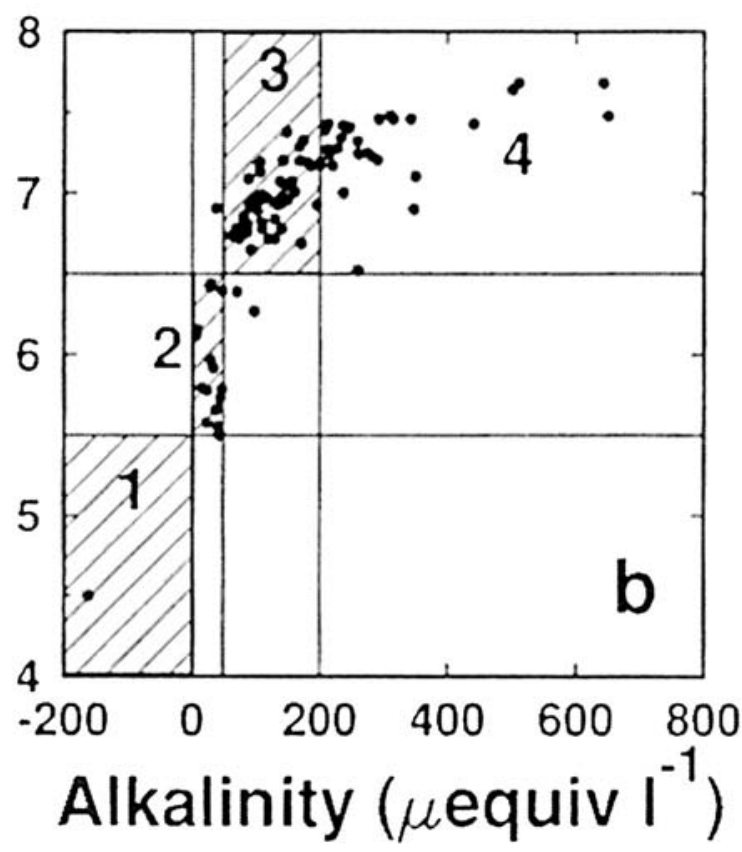

Figure 12. Diagram pH - Alkalinity for lakes in the Pyrenees. The graph was divided in four areas, according to the acid status of lakes enclosed: 1 - acid lakes (acid neutralizing capacity exhausted); 2 - very sensitive lakes (acidification may affect some organisms); 3 - sensitive lakes (susceptible to reach occasionally low pH); 4 - Non-sensitive lakes. Diagrama $\mathrm{pH}$ Alcalinidad para lagos de los Pirineos. El gráfico se ha dividido en cuatro sectores relacionados con el estado de acidez de los lagos incluidos: 1- lagos ácidos (con la capacidad neutralizadora de ácidos agotada); 2 - lagos muy sensibles (la acidificación puede afectar a algunos organismos); 3 - lagos sensibles (susceptibles de alcanzar ocasionalmente un pH bajo); 4 - lagos no sensibles.

\section{Persistent organic pollutants}

For the first time in the history of the life, the organisms are submitted to low doses of a complex cocktail of toxic substances, many of them nonexistent before. The distribution and bioconcentration of these substances are not uniform, because the emission points are different and the facility of transport, accumulation and destruction vary among them. In the last decade, it has been observed that some organic pollutants such as the semi-volatile organochlorine (OCs) compounds are transferred from tempered areas, where they were produced and used, to cold distant points without significant dilution (Breivik et al., 2002). The natural processes of volatilisation and absorption along with the atmospheric transport give rise to their accumulation in ecosystems and organisms of high latitudes (Wania and Mackay, 1993). In this context, it has been demonstrated that there is also a tendency to the accumulation of these compounds in altitude due to decreasing temperatures with elevation (Grimalt et al., 2001). The patterns of deposition of these compounds probably will be under the influence of the climatic change in the immediate future, since its retention in the zones of fresh water accumulation after the atmospheric transport depends on local weather conditions (Carrera et al., 2002; Van Drooge et al., 2004; Meijer et al., 2006).

The analysis of OCs in muscle of fish from high mountain lakes shows that part of their variability depends on fish age and lake altitude. The interesting point is that the degree of dependency decreases with the vapour pressure of the compound $\left(\mathrm{V}_{\mathrm{p}}\right)$, thus the distribution of OC with $\mathrm{V}_{\mathrm{p}}<10^{-2.5}$ are mostly determined by these two variables (Vives et al., 2004). Altitude gradients mainly respond to temperature differences, and absorption effects as suggested by the global distillation theory can partially explain the results. However, OC accumulation in fish is higher than predicted from theoretical absorption and solubilisation enthalpies, which implies that there is an additional temperature-dependent amplification mechanisms, which is at present one of our research objectives (Catalan et al., 2004). At present trophic relations are studied following an altitudinal gradient. In these small and oligotrophic systems food webs are short and the interactions between the different compartments are suitable to be traced. Bioenergetics models and stable isotopes are used to provide energy flowbased measures of food web structure, while some OCs are used as tracers of bioconcentration and biomagnification processes.

The overall environmental concentrations of polycyclic aromatic hydrocarbons (PAHs) have increased extensively in the $20^{\text {th }}$ century as a result of a general increase of the combustion processes. These compounds and their metabolites have been studied widely because of their carcinogenic and mutagenic properties. In this 
respect, recent studies on sediments, water, and air have demonstrated that these compounds are significant pollutants of high mountain lake areas (Fernández et al., 2003). PAHs transport to remote areas depends on the dust deposition and therefore is under the influence of climatic variations. Whereas fish possess mixed-function oxygenase systems that rapidly metabolise PAHs, these enzymes are poorly developed in some invertebrates and, as a consequence, they have a lower rate of metabolic degradation. Therefore, low PAH concentrations in fish do not necessarily imply that they are not receiving significant pollutant fluxes and they are free of stress. High mountain lakes offer unique environments for the assessment of the transfer mechanisms of atmospherically transported pollutants into biota. In lake Redon, we investigated the contents of PAHs in the food web organisms included in the diet of brown trout (Vives et al., 2005). The preferential habitat and trophic level of the component species were assessed from the signature of stable isotopes $\left(\delta^{13} \mathrm{C}\right.$ and $\left.\delta^{15} \mathrm{~N}\right)$. Most of the organisms exhibit PAH distributions largely dominated by phenanthrene, which agrees with its predominance in atmospheric deposition, water, and suspended particles. Total PAH levels are higher in the organisms from the littoral habitat that from the deep sediments or the pelagic water column. Therefore, PAH levels in trout highly depend on organisms living in the littoral areas. Fish exposure to PAH, therefore, may vary from lake to lake according to the relative contribution of littoral organisms to their diet. The reasons why PAH concentrations are higher in littoral organisms still need to be elucidated.

\section{Climate change(s)}

\section{Development of new proxies}

Climate change research has taken additional relevance with the realisation that human activities can accelerate climate changes. Hence longterm records are necessary to assess climate fluctuations. However, long-term instrumental meteorological records are scarce. That need have increased the interest to develop new techniques to reconstruct past climatic fluctuations using a diversity of proxies (ice cores, speleothems, boreholes, tree rings, paleolimnology, pollen, etc). During the last decades palaeolimnology has largely been used to assess and reconstruct environmental problems related to acidification and eutrophication in a quantitative way. The methods developed in this approach are now being applied to reconstruct pass climatic conditions complementing more traditional approaches (Battarbee, 2000). Although changes in algal assemblages are relatively straightforward linked to changes in some limnological conditions (e.g. $\mathrm{pH}$, phosphorus), translation into climatic information and direct reconstruction of climate components are more difficult. For instance, diatoms have been used as a climate proxy indirectly by their response to conductivity changes, assuming that they are ultimately related to changes in the balance between precipitation and evaporation (Fritz et al., 1991) and changes in diatom inferred $\mathrm{pH}$ have been related to past climatic conditions (Psenner \& Schmidt, 1992). There is no an ideal proxy for climate reconstruction, each proxy has also its advantages and shortcomings; properties such as sensitivity, reproducibility, local availability and continuity through time differ among them (Mann, 2002). As a consequence, it is worth to use different approaches to reconstruct climate. In that line, in our group we have recently dedicated some effort to improve the use of chrysophyte cysts for climate reconstructions.

Chrysophytes (Classes Chrysophyceae and Synurophyceae) are often a key component of phytoplankton in temperate oligotrophic and mountain lakes, where they exhibit a distinct seasonality and are present in a wide range of environmental conditions. Their siliceous resting stages, referred to as cysts or stomatocysts, are common in lake sediment and the composition of the assemblages often reflects their surrounding physico-chemical environment. As a result, chrysophyte cyst stages have been used in paleolimnological studies to assist in environmental reconstructions. Climate fluctuations can affect the abundance and composition of chrysophytes 
by influencing water temperature, modifying resource availability (light, nutrients), other limnological conditions $(\mathrm{pH}$, alkalinity, redox) or the physical system (extent of ice cover, duration of summer stratification, mixing patterns) (Smol $\&$ Cumming, 2000). Given the number of factors and the complexity of the processes involved, a mechanistic model relating a climatic parameter (e.g. air temperature) to chrysophyte cyst composition becomes intractable at the present. However, statistical approaches are possible and attends have been done. In a recent paper (Pla \& Catalan, 2005), we studied the cyst distributions in modern surface sediment samples from a set of high mountain lakes in the Pyrenees. The lakes studied covered a broad range of altitude, size, and bedrock and vegetation types. Altitude can be considered a surrogate for climate (lapse rates), therefore with a series of multivariate analyses we tested whether altitude was a significant factor in determining chrysophyte cyst distributions, and to what extent it is independent from other factors. Interestingly, altitude appeared to be orthogonal to the first axis of variability defined by different bedrocks. In other words, a significant part of the variability in the distribution of chrysophyte cysts was related to altitude and was independent of the chemical characteristics of the water, which are usually the main factor of stomatocysts variability (Pla et al., 2003). Therefore, in the course of the history of a lake, in which the range of the water chemical fluctuations is certainly narrower than in the set of lakes surveyed, we could expect that changes in chrysophyte cysts could be reliable indicators of changes in climate. Based on these results, we developed a model to reconstruct altitude anomalies using cyst sediment records. The chrysophyte cysts assemblages in high mountain lakes appear related to winter/spring climate components that determine the length of the ice cover. Therefore, the use of the chrysophyte cyst records for climate reconstructions may provide a valuable complement to other proxies that are more influenced by the conditions during the warm season, such is the case of terrestrial vegetation. Moreover conversion to mean winter/spring temperatures can be intended using present lapse rates (Agusti-Panareda \& Thompson, 2002). Although there is no guarantee that those lapse rates were constant throughout long time periods.

The method was applied to a Holocene record from a lake in the Pyrenees showing the submillennial climatic variability in this northwestern Mediterranean zone. A warming trend was present from the early Holocene to $4 \mathrm{ky} \mathrm{BP}$. Comparison with pollen-based reconstructions of summer temperatures denoted a contrasting decrease in continentality between the two parts of the Holocene. Oscillations of one cycle per ca. 2000 years appeared throughout the record. The warmest Holocene winters were recorded during the Medieval Warm Period at ca. AD 900 and 450 and the Roman Warm Period (2.7-2.4 ky BP). Winters in the period AD 1050-1175 were inferred to be as cold as in the Little Ice Age. The period between 3 and 7 ky BP showed lower intensity in the fluctuations than early and late Holocene. The 8200 years ago cold event appeared embedded in a warm fluctuation. Another cold fluctuation was recorded around $9 \mathrm{ky} \mathrm{BP}$, in agreement with Irish and Greenland records (Fig. 13). At present, our research in this topic focuses in combining this method with other proxies to obtain a reconstruction of the seasonal components of climate in the Pyrenees throughout the Holocene and Late Glacial periods.

\section{Present climate change}

There is an increasing recognition that alpine aquatic ecosystems are influenced by present climate change (Battarbee et al., 2002a). The interaction between climate and lake dynamics, however, is complex and involves many direct and indirect catchment mediated processes. For a particular lake, some clues may be given by statistical comparison between the instrumental meteorological records and a high-resolution study of the sediment record. This was the approach undertaken in the European Mountain Lake Research project, MOLAR (Battarbee et al., $2002 \mathrm{~b}$ ). In the case of the Pyrenees, the ecosystem response of Lake Redon to fluctuations in seasonal air temperature during the last two cen- 


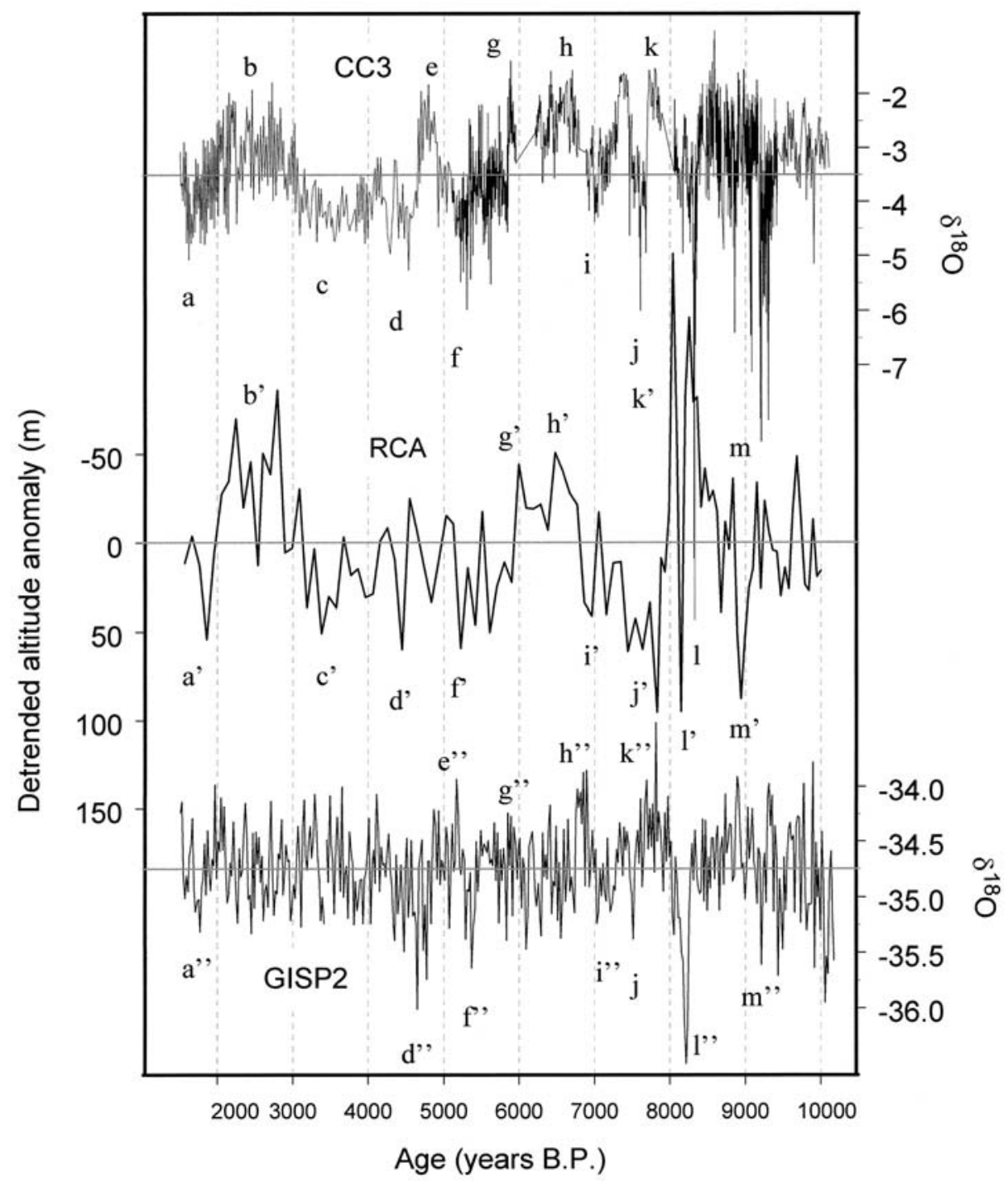

Figure 13. Comparison of the detrended altitude anomaly in Lake Redon throughout the Holocene (core RCA94) with $\mathrm{d}^{18} \mathrm{O}$ data of the CC3 speleothem record in Ireland (McDermott et al. 2001) and the GISP2 ice-core bidecadal record from Greenland (Stuiver et al., 1997). Comparación de la anomalía de altitud a lo largo del Holoceno en el lago Redon, extraída la tendencia, con registros de $d^{18} \mathrm{O}$ de espeleotemas en Irlanda (McDermott et al. 2001) y del testimonio de hielo GISP2 de Groenlandia (Stuiver et al., 1997).

turies was investigated (Catalan et al., 2002a). Fine slicing allowed a resolution of 3 to 6 years according to the ${ }^{210} \mathrm{~Pb}$ dating, which was still not enough to easily investigate the response to air temperature forcing, since extreme fluctuations in temperature occur on the interannual time scales. However, the resolution was sufficient to show up responses on decadal and century scales. An overall tendency to warming in mean annual temperature in the Central Pyrenees has been caused by summer and in particular by autumn increases. Many of the measured sediment variables apparently responded to these long-term trends, but the significance of the relationships was highly conditioned by the structure of the data. The variables responding most on the finer time scales were the microfossils. For diatoms and chironomids, the main variability correlated to summer and to autumn temperatures. For two planktonic species, Fragilaria nanana and 


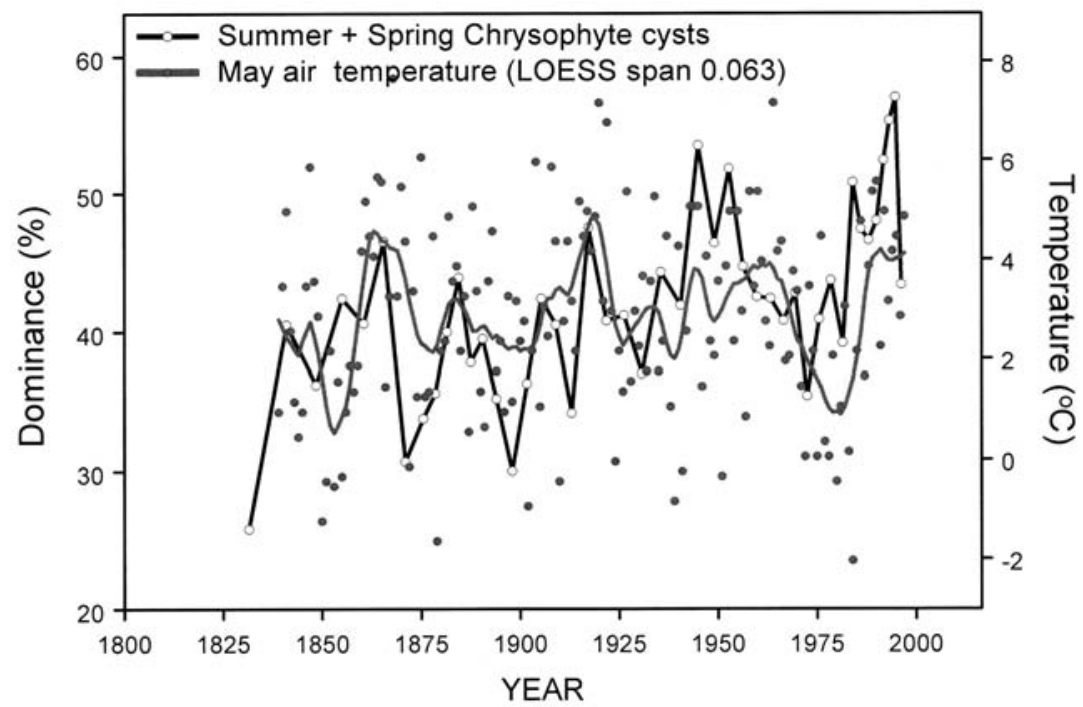

Figure 14. Comparison between mean monthly air temperature of May, smoothed (LOESS span 0.063) temperatures and the record for chrysophyte cysts growing during spring and summer in Lake Redon. Comparación entre la temperatura media del aire para el mes de mayo, la misma señal suavizada (LOESS span 0.063) y el registo de cistes de crisófitas que crecen durante primavera y verano en el lago Redon.

Cyclotella pseudostelligera, we found a link of their variability with temperature fluctuations in their growing months (September and October, respectively). This relationship appeared at certain point during a general warming trend, indicating a threshold in the response. On the other hand, no significant changes in the dominant species could be linked to temperature, or in any significant subgroup of the 180 diatom species present in the core. Increase in planktonic diatoms have been observed all over the north hemisphere from Arctic to Alpine lakes and some authors suggest that lake stratification periods could be the driving factor (Sorvari \& Korhola, 1998). But in the Arctic there are also several alternative explanations, such as the existence of an icefree season or not; permafrost degradation or not; lake change from monomictic to polimictic (Smol et al., 2005). In the lakes located in the Rock Mountains (USA), the raise in planktonic diatoms was related to nitrogen deposition increase (Saros et al., 2003; Wolfe et al., 2003) or other sources of atmospheric pollution (Solovieva et al., 2002). For most chironomids (particularly Paratanytarsus austriacus, Heterotrissocladius marcidus and Micropsectra radialis) a negative relationship with summer temperature extended throughout the study period. This response of the whole group suggest that chironomids can be particularly robust role as indicators of temperature changes on long time scales (e.g. through the Holocene) and for lake signal inter-comparison. Chrysophyte cysts were correlated with April-May air temperatures (Fig. 14). Weather during this period of time during spring determines the timing of ice out in lake Redon, which influences chlorophyll distribution patterns in the lake throughout the growing season (Ventura et al., 2000; Catalan, 2000). Finally, our results indicated that in all cases, there was a high resistance to occasional extreme fluctuations, the whole system showing a large hysteresis in its response. Although we were dealing with organisms with one or many generations per year, their populations seemed to follow the decadal trends in air temperature. If we extrapolate those results to long living organisms, we have to assume that populations' changes in response to present climate change will be hardly detectable at their initial stages for some decades, unless non-linear dynamics resulted into unpredictable abrupt changes. Behavioural and phenological responses can provide better early clues (Peñuelas and Filella, 2003). 


\section{ACKNOWLEDGMENTS}

Since Dr. Margalef stirred up our research in the lakes of the Pyrenees in the early 80's, he evolved from being our adviser to become a confident to share victories and miseries, enthusiasm and ironies. We miss him very much. All we have done in the past and all we could do in the future is a tribute to him. The authors of the present paper integrated the research group when we started the manuscript. In addition to them, other researchers have contributed significantly to the activities of the group during the last 20 years, in particular, we want to mention Enric Ballesteros, Esperança Gacia, John Donato, Silvana Halac and Jaume Piera. We want also to acknowledge the myriad of researchers from other institutions that have co-authored publications and with many of whom a friendship was built during several years of cooperation.

\section{BIBLIOGRAPHY}

AGUSTI-PANAREDA, A. \& R. THOMPSON. 2002. Retrodiction of air temperature at eleven remote alpine and arctic lake in Europe from 1781 to 1997. J. Paleolimnol., 28: 7-23.

ALFREIDER, A., J. PERNTHALER, R. AMANN, B. SATTLER, A. WILLE, \& R. PSENNER. 1996. Community analysis of the bacterial assemblages in the winter cover and pelagic layers of a high mountain lake by in situ hybridization. Appl. Environ. Microb., 62: 2138-2144.

ARIES, S. 2001 Mise en évidence de contaminations métalliques historiques à partir de l'étude d'enregistrements sédimentaires de lacs de haute montagne. Ph. D. Thesis, Université Toulouse III Paul Sabatier. 276 pp.

ARRANZ, E. 1991 Petrología, estructura y geoquímica de los granitoides del macizo de la Maladeta en su sector Tahull-Lago Negro (provincia de Lérida). M. Sc. Thesis. University of Zaragoza. $173 \mathrm{pp}$.

ATKINSON, R. P. D., C. J. RHODES, D. W. MACDONALD \& R. M. ANDERSON. 2002. Scalefree dynamics in the movement patterns of jackals. Oikos, 98: 134-140.

AUSTIN, D., W. D. BOWEN \& J. I. MCMILLAN. 2004. Intraspecific variation in movement pat- terns: modeling individual behavior in a large marine predator. Oikos, 105: 15-30.

BARTUMEUS, F,. J. CATALAN, U. L. FULCO, M. L. LYRA \& G. M. VISWANATHAN. 2002. Optimizing the encounter rate in biological interactions: Lévy vs. Brownian strategies. Phys. Rev. Lett., 88: 97901-97904.

BARTUMEUS, F., M. G. E. DA LUZ, G. M. VISWANATHAN \& J. CATALAN. 2005. Animal search strategies: a quantitative random walk analysis. Ecology, 86: 3078-3087.

BARTUMEUS, F., F. PETERS, S. PUEYO, C. MARRASÉ \& J. CATALAN. 2003. Helical Lévy walks: Adjusting searching statistics to resource availability in microzooplankton. P. Natl. Acad. Sci. USA, 100: 12771-12775.

BATTARBEE, R. W. 2000. Palaeolimnological approaches to climate change, with special regard to the biological record. Quaternary Sci. Rev., 19: 107-124.

BATTARBEE, R. W., J. A. GRYTNES, R. THOMPSON, P. G. APPLEBY, J. CATALAN, A. KORHOLA, H. J. B. BIRKS, E. HEEGAARD \& A. LAMI. 2002a. Comparing palaeolimnological and instrumental evidence of climate change for remote mountain lakes over the last 200 years. $J$. Paleolimnol., 28: 161-179.

BATTARBEE, R. W., V. J. JONES, R. J. FLOWER, N. G. CAMERON, H. BENNION, L. CARVALHO \& S. JUGGINS. 2001. Diatoms. In: Terrestial, Algal and Siliceous Indicators. J. P. Smol, H. J. B. Birks, \& W. M. Last (eds.): 203-224. Kluwer Academic Publishers, Dordrecht.

BATTARBEE, R. W., R. THOMPSON, J. CATALAN, J. A. GRYTNES \& H. J. B. BIRKS. 2002b. Climate variability and ecosystem dynamics of remote alpine and arctic lakes: the MOLAR project. J. Paleolimnol., 28: 1-6.

BERG, H. C. 1983. Random walks in biology. Princeton University Press. Princeton. 152 pp.

BRADFORD, D. F., S. D. COOPER, T. M. JENKINS, K. KRATZ, O. SARNELLE \& A. D. BROWN. 1998. Influences of natural acidity and introduced fish on faunal assemblages in California alpine lakes. Can. J. Fish. Aquat. Sci., 55: 2478-2491.

BREIVIK, K., A. SWEETMAN, J. M. PACYNA \& K. C. JONES. 2002. Towards a global historical emission inventory for selected PCB congeners- a mass balance approach. Sci. Total Environ., 290: 181-198.

BUCHACA, T., M. FELIP \& J. CATALAN. 2005. A comparison of HPLC pigment analyses and biovo- 
lume estimates of phytoplankton groups in an oligotrophic lake. J. Plankton Res., 27: 91-101.

BUCHACA, T. 2005. Pigments indicadors: estudi del senyal en estanys dels Pirineus I de la seva aplicació en paleolimnologia. Tesi doctoral. Universitat de Barcelona. Barcelona. 212 pp.

CAMARERO, L. 2003. Spreading of trace metals and metalloids pollution in lake sediments over the Pyrenees. J. Phys. IV France, 107: 249-253

CAMARERO, L. \& J. CATALAN. 1993. Chemistry of bulk precipitation in the Central and Eastern Pyrenees (Northeast Spain). Atmos. Environ., 27A: 83-94.

CAMARERO, L. \& J. CATALAN. 1996. Variability in the chemistry of precipitation in the Pyrenees (northeastern Spain): Dominance of storm origin and lack of altitude influence. J. Geophys. Res., 101: 29491-29498.

CAMARERO, L. \& J. CATALAN. 1998. A simple model of regional acidification for high mountain lakes: Application to the Pyrenean lakes (NorthEast Spain). Wat. Res., 32: 1126-1136.

CAMARERO, L., J. CATALAN, A. BOGGERO, A. MARCHETTO, R. MOSELLO \& R. PSENNER. 1995. Acidification in high mountain lakes in Central, Southwest and Southeast Europe (Alps, Pyrenees, Pirin). Limnologica, 25: 141-156.

CAMARERO, L., P. MASQUÉ, W. DEVOS, I. ANIRAGOLTA, J. CATALAN, H.C. MOOR, S. PLA \& J.A. SÁNCHEZ-CABEZA. 1998. Historical variations in lead fluxes in the Pyrenees (NE Spain) from a dated lake sediment core. Wat. Air Soil Pol., 105: 439-449.

CAMARERO, L., R. F. WRIGHT, J. CATALAN \& M. VENTURA. 2004. Application of MAGIC to Lake Redo (Central Pyrenees): an assessment of the effects of possible climate driven changes in atmospheric precipitation, base cation deposition, and weathering rates on lake water chemistry. $J$. Limnol., 63: 123-132.

CARRERA, G., P. FERNÁNDEZ, J. O. GRIMALT, M. VENTURA, L. CAMARERO, J. CATALAN, U. NICKUS, H. THIES \& R. PSENNER. 2002. Atmospheric deposition of organochlorine compounds to remote high mountain lakes of Europe. Environ. Sci. Technol., 36: 2581-2588.

CARRILLO, P., J. M. MEDINA-SÁNCHEZ \& M. VILLAR-ARGAIZ. 2002. The interaction of phytoplankton and bacteria in a high mountain lake: importance of the spectral composition of solar radiation. Limnol. Oceanogr., 47: 12941306.
CASAMAYOR, E. O., C. PEDRÓS-ALIÓ, G. MUYZER \& R. AMANN. 2002. Microheterogeneity in $16 \mathrm{~S}$ rDNA-defined bacterial populations from a stratified planktonic environment is related to temporal changes and to ecological adaptations. Appl. Environ. Microb., 68: 1706-1714.

CASAMAYOR, E. O., H. SCHÄFER, L. BAÑERAS, C. PEDRÓS-ALIÓ \& G. MUYZER. 2000. Identification of and spatio-temporal differences between microbial assemblages from two neighboring sulfurous lakes: comparison by microscopy and denaturing gradient gel electrophoresis. Appl. Environ. Microb., 66: 499-508.

CATALAN, J. 1989. The winter cover of a highmountain mediterranean lake (Estany Redó, Pyrenees). Wat. Resour. Res., 25: 519-527.

CATALAN, J. 1992. Evolution of dissolved and particulate matter during the ice-covered period in a deep, high mountain lake. Can. J. Fish. Aquat. Sci., 49: 945-955.

CATALAN, J. 1999. Small-scale hydrodynamics as a framework for plankton evolution. The Japanese Journal of Limnology, 60: 469-494.

CATALAN, J. 2000. Primary production in a high mountain lake: an overview from minutes to kiloyears. Atti della Associazione Italiana di Oceanologia e Limnologia, 13: 1-21.

CATALAN, J., E. BALLESTEROS, E. GACIA, A. PALAU \& L. CAMARERO. 1993 Chemical composition of disturbed and undisturbed high mountain lakes in the Pyrenees: a reference for acidified sites. Wat. Res., 27: 133-141.

CATALAN, J. \& L. CAMARERO. 1991. Ergoclines and biological processes in high mountain lakes: similarities between summer stratification and the ice-forming periods in Lake Redo. Verh. Internat. Verein. Limnol., 24: 1011-1015.

CATALAN, J., S. PLA, M. RIERADEVALL, M. FELIP, M. VENTURA, T. BUCHACA, L. CAMARERO, A. BRANCELJ, P. G. APPLEBY, A. LAMI, A. GRYTNES, A. AGUSTI-PANAREDA \& R. THOMPSON. 2002a. Lake Redo ecosystem response to an increasing warming in the Pyrenees during the twentieth century. J. Paleolimnol., 28: 129-145.

CATALAN, J., M. VENTURA, A. BRANCELJ, I. GRANADOS, H. THIES, U. NICKUS, A. KORHOLA, A. F. LOTTER, A. BARBIERI, E. STUCHLIK, L. LIEN, P. BITUSÍK, T. BUCHACA, L. CAMARERO, G. H. GOUDSMIT, J. KOPACEK, G. LEMCKE, D. M. LIVINGSTONE, B. MÜLLER, M. RAUTIO, M. SISKO, S. SOR- 
VARI, F. SPORKA, O. STRUNECKY \& M. TORO. 2002b. Seasonal ecosystem variability in remote mountain lakes: implications for detecting climatic signals in sediment records. $J$. Paleolimnol., 28: 25-46.

CATALAN, J., M. VENTURA, I. VIVES \& J. O. GRIMALT. 2004. The roles of food and water in the bioaccumulation of organochlorine compounds in high mountain lake fish. Environ. Sci. Technol., 38: 4269-4275.

CATALAN, J., R. VILALTA, B. WEITZMAN, C. PIGEM, M. VENTURA, R. ARANDA, E. COMAS, S. PLA \& E. BALLESTEROS. 1997. L'obra hidràulica en els Pirineus: avaluació, correcció i prevenció de l'impacte mediambiental. El Parc Nacional d'Aiguestortes $i$ estany de Sant Maurici. Fundació la Caixa. Barcelona. 583 pp.

CURTIS, C. J., I. BOTEV, L. CAMARERO, J. CATALAN, D. COGALNICEANU, M. HUGHES, M. KERNAN, J. KOPACEK, A. KORHOLA, R. PSENNER, M. ROGORA, E. STUCHLIK, M. VERONESI \& R.F. WRIGHT. 2005. Acidification in European mountain lake districts: a regional assessment of critical load exceedance. Aquat. Sci., 67: 237-251.

FELIP, M., F. BARTUMEUS, S. HALAC \& J. CATALAN. 1999a. Microbial plankton assemblages, composition and biomasa, during two ice-free periods in a deep high mountain lake (Estany Redó, Pyrenees). J. Limnol., 58: 193-202.

FELIP, M., L. CAMARERO \& J. CATALAN. 1999 b. Temporal changes of microbial assemblages in the ice and snow cover of a high mountain lake. Limnol. Oceanogr., 44: 973-987.

FELIP, M. \& J. CATALAN. 2000. The relationship between phytoplankton biovolume and chlorophyll in a deep oligotrophic lake: decoupling in their spatial and temporal maxima. J. Plankton Res., 22: 91-105.

FELIP, M, B. SATTLER, R. PSENNER \& J. CATALAN. 1995. Highly active microbial communities in the ice and snow cover of high mountain lakes. Appl. Environ. Microb., 61: 2394-2401.

FELIP, M., A. WILLE, B. SATTLER \& R. PSENNER. 2002. Microbial communities in the ice and snow cover of an alpine lake: evidence for general patterns, and lake-cover relationship. Aquat. Microb. Ecol., 29: 123-134.

FERNÁNDEZ, P., G. CARRERA, J. O. GRIMALT, M. VENTURA, L. CAMARERO, J. CATALAN, U. NICKUS, H. THIES \& R. PSENNER. 2003. Factors governing the atmospheric deposition of polycyclic aromatic hydrocarbons to remote areas. Environ. Sci. Technol., 37:3261-3267.

FRITZ, S. C., S. JUGGINS, R. W. BATTARBEE, D. R. ENGSTROM. 1991. Reconstruction of past changes in salinity and climate using a diatombased transfer function. Nature, 352: 706-708.

GACIA, E. \& E. BALLESTEROS. 1996. The effect of increased water level on Isoetes lacustris $\mathrm{L}$ in Lake Baciver, Spain. J. Aquat. Plant Manage., 34: 57-59. GACIA, E., E. BALLESTEROS, L. CAMARERO, O. DELGADO, A. PALAU, J. L. RIERA \& J. CATALAN. 1994. Macrophytes from lakes in the eastern Pyrenees: community composition and ordination in relation to environmental factors. Freshwat. Biol., 32: 73-81.

GERRITSEN, J. \& J. R. STRICKLER. 1977. Encounter probabilities and community structure in zooplankton: a mathematical model. J. Fish. Res. Board Can., 34: 73-82.

GILINSKY, E., 1984. The role of fish predation and spatial heterogeneity in determining benthic community structure. Ecology, 65: 455-468.

GLIWICZ, Z. M., A. SLUSARCZYK \& M. SLUSARCZYK. 2001. Life history synchronization in a long-lifespan single-cohort Daphnia population in a fishless alpine lake. Oecologia, 128: 368-378.

GOTELLI, N. J. \& R. K. COLWELL, 2001. Quantifying biodiversity: procedures and pitfalls in the measurement and comparison of species richness. Ecol. Lett., 4: 379-391.

GRANBERG, H. B. 1985 Distribution of grain sizes and internal surface area and their role in snow chemistry in a sub-artic snow cover. Ann. Glaciol., 7: 149-152.

GEIDER, R. J. 1987. Light and temperature dependence of the carbon to chlorophyll ratio in microalgae and cyanobacteria: implications for physiology and growth of phytoplankton. New Phytol., 106: 1-34.

GEIDER, R. J., H. L. MACINTYRE \& T. M. KANA. 1997. Dynamic model of phytoplankton growth and acclimation: responses of the balanced growth rate and the chlorophyll a: carbon ratio to light, nutrient-limitation and temperature. Mar. Ecol. Prog. Series, 148: 187-200.

GOODALE, C. L., J. D. ABER, P. M. VITOUSEK \& W. H. MCDOWELL. 2005. Long-term decreases in stream nitrate: Successional causes unlikely; Possible links to DOC? Ecosystems, 8: 334-337.

GRIMALT, J.O., P. FERNANDEZ, L. BERDIE, R. M. VILANOVA, J. CATALAN, R. PSENNER, R. HOFER, P. G. APPLEBY, B. O. ROSSELAND, L. 
LIEN, J. C. MASSABUAU \& R. W. BATTARBEE. 2001. Selective Trapping of Organochlorine Compounds in Mountain Lakes of Temperate Areas. Environ. Sci. Technol., 35: 2690-2697.

HALAC, S., M. FELIP, LL. CAMARERO, S. SOMMARUGA-WÖGRATH, R. PSENNER, J. CATALAN, \& R. SOMMARUGA. 1997. An in situ enclosure experiment to test the solar UV-B impact on plankton in a high altitude mountain lake: I) lack of effect on phytoplankton species composition and growth. J. Plankton Res., 19: 1671-1686.

HSIAO, S. 1992. Dynamics of ice algae and phytoplankton in Frobisher Bay. Polar Biol., 12: 645-651

JOHANNESEN, M. \& A. HENRIKSEN. 1978 Chemistry of snow meltwater: changes in concentration during melting. Wat. Resour. Res., 14: 615-619.

JUMARS, P. A. 1993. Concepts in biological oceanography: An interdisciplinary primer. Oxford University Press, New York. 348 pp.

KIORBOE, T. 1997. Small-scale turbulence, marine snow formation, and planktivorous feeding. Sci. Mar., 61: 141-158.

KNAPP, R. A., K. R. MATTHEWS \& O. SARNELLE. 2001. Resistance and resilience of alpine lake fauna to fish introductions. Ecol. Monogr., 71: 401-421.

KOPÁČEK, J., E. STUCHLÍK \& R. F. WRIGHT. 2005. Long-term trends and spatial variability in nitrate leaching from alpine catchment-lake ecosystems in the Tatra Mountains (Slovakia-Poland). Environ. Pol.,136: 89-101.

LAURION, I., M. VENTURA, J. CATALAN, R. PSENNER \& R. SOMMARRUGA. 2000 Attenuation of ultraviolet radiation in mountain lakes: Factors controlling the among- and within-lake variability. Limnol. Oceanogr., 45: 1274-1288.

LEE, R. \& J. HIROTA. (1973) Wax esters in tropical zooplankton and nekton and the geographical distribution of wax esters in marine copepods. Limnol. Oceanogr., 18: 227-239.

LEVANDOWSKY, M., J. KLAFTER, J. \& B. S. WHITE. 1988a. Feeding and swimming behavior in grazing microzooplankton. J. Protozool., 35: 243-246.

LEVANDOWSKY, M., J. KLAFTER, J. \& B. S. WHITE. 1988b. Swimming behavior and chemosensory responses in the protistan microzooplankton as a function of hydrodynamic regime. B. Mar. Sci., 43: 758-763.

LEVANDOWSKY, M., B. S. WHITE \& F. SCHUSTER. 1997. Random movements of soil amoebas. Acta Protozool., 36: 237-248.
LEVIN, S. A \& R. DURRET. 1996. From individuals to epidemics. Phil. Trans. Royal Soc. London, series $B, 351$ : 1615-1621.

MACKENZIE, B. R. \& T. KIORBOE. 1995. Encounter rates and swimming behavior of pausetravel and cruise larval fish predators in calm and turbulent laboratory environments. Limnol. Oceanogr., 40: 1278-1289.

MANDELBROT, B. B. 1977. Fractals: Form, chance and dimension. Freeman, W.H and Co. San Francisco. 265 pp.

MANN, M. E. 2002. The value of multiproxies. Science, 297: 1481-1482.

McDERMOTT F., D. P. MATTEY \& C. HAWKESWORTH. 2001. Centennial-scale Holocene climate variability revealed by a high-resolution speleothem $\mathrm{d}^{18} \mathrm{O}$ record from SW Ireland. Science, 294: 1328-1330.

MEDINA-SÁNCHEZ, J. M., M. FELIP \& E. O. CASAMAYOR. 2005 Catalyzed Reported Deposition-Fluorescence In Situ Hybridization protocol to evaluate phagotrophy in mixotrophic protists. Appl. Environ. Microb., 71: 7321-7326.

MEDINA-SÁNCHEZ, J. M., M. VILLAR-ARGAIZ \& P. CARRILLO. 2002. Modulation of the bacterial response to spectral solar radiation by algae and limiting nutrients. Freshwat. Biol., 47: 2191-2204.

MEDINA-SÁNCHEZ, J. M., M. VILLAR-ARGAIZ \& P. CARRILLO. 2004. Neither with nor without you: A complex algal control on bacterioplankton in a high mountain lake. Limnol. Oceanogr., 49: 1722-1733.

MEDINA-SÁNCHEZ, J. M., M. VILLAR-ARGAIZ \& P. CARRILLO. 2006. Solar radiation-nutrient interaction enhances the resource and predation algal control on bacterioplankton: A short-term experimental study. Limnol. Oceanogr., 51: 913-924.

MEIJER S. N., J. DACHS, P. FERNANDEZ, L. CAMARERO, J. CATALAN, S. DEL VENTO, B. VAN DROOGE, E. JURADO \& J. O. GRIMALT. 2006. Modelling the dynamic air-water-sediment coupled fluxes and occurrence of polychlorinated biphenyls in a high altitude lake. Environ. pol., 140: 546-560.

MIRÓ, A. \& M. VENTURA. 2004. Història de la truita I alters peixos en el estanys del Parc Nacional d'Aigüestortes i Estany de Sant Maurici. VI Jornades de recerca en el Parc nacional d'Aigüestortes i Estany de Sant Maurici Nacional Park. pp: 187-208.

MORRIS, D. P., H. ZAGARESE, C. E. WILLIAMSOM, E. G. BALSEIRO, B. R. HARGREAVES, B. MODENUTTI, R. MOELLER \& C. QUEIMA- 
LINOS. 1995. The attenuation of solar UV radiation in lakes and the role of dissolved organic carbon. Limnol. Oceanogr., 40: 1381-1391.

MOSEllo, M., A. LAMI, A. MARCHETTO, M. ROGORA, B. WATHNE, L. LIEN, J. CATALAN, L. CAMARERO, M. VENTURA, R. PSENNER, K. KOINIG, H. THIES, S. SOMMARUGAWÖGRATH, U. NICKUS, D. TAIT, B. THALER, A. BARBIERI \& R. HARRIMAN. 2002. Trends in the chemical composition of high altitude lakes selected for the MOLAR project. Wat. Air Soil Pol. Focus, 2: 75-89.

NRIAGU, J. O. 1996. A history of global metal pollution. Science, 272: 223-224.

OKUBO, A. 1980. Diffusion and ecological problems: Mathematical models. Springer-Verlag. Berlin. $254 \mathrm{pp}$.

PEDRÓS-ALIO C. \& R. GUERRERO. 1994. Prokaryotology for the limnologist. In: Limnology Now: A Paradigm of Planetary Problems, R. Margalef (ed.): 37-57. Elsevier Science B.V., Amsterdam.

PEÑUELAS, J. \& I. FILELLA. 2003. Phenology: responses to a warming world. Science, 294: 793.

PERNTHALER, J., F. O. GLÖCKNER, S. UNTERHOLZNER, A. ALFREIDER, R. PSENNER \& R. AMANN. 1998. Seasonal community and population dynamics of pelagic Bacteria and Archaea in a high mountain lake. Appl. Environ. Microb., 64: 4299-4306.

PLA, S., L. CAMARERO \& J. CATALAN. 2003. Chrysophyte cyst relationships to water chemistry in Pyrenean lakes (NE Spain) and their potential for environmental reconstruction. J. Paleolimnol., 30: 21-34.

PLA, S. \& J. CATALAN. 2005. Chrysophyte cysts from lake sediments reveal the submillennial winter/spring climate variability in the northwestern Mediterranean region throughout the Holocene. Clim. Dynam., 24: 263-278.

PSENNER, R. \& J. CATALAN. 1994. Chemical composition of lakes in crystalline basins: a combination of atmospheric deposition, geologic background, biological activity and human action. In: Limnology Now: a paradigm of planetary problems. R. Margalef (ed.): 255-314. Elsevier. Amsterdam. The Netherlands.

PSENNER, R. \& R. SCHMIDT. 1992. Climate-driven $\mathrm{pH}$ control of remote alpine lakes and effects of acid deposition. Nature, 781-783.

RAMOS-FERNÁNDEZ, G., J. L. MATEOS, O. MIRAMONTES, G. COCHO, H. LARRALDE \&
B. AYALA-OROZCO. 2004. Lévy walk patterns in the foraging movements of spider monkeys (Ateles geoffroyi). Behav. Ecol. Sociobiol., 55: 223-230.

RAPOSO, E. P., S. V. BULDYREV, M. G. E. DA LUZ, M. C. SANTOS, H. E. STANLEY \& G. M. VISWANATHAN. 2003. Dynamical robustness of Lévy search strategies. Phys. Rev.Lett., 91: 2-4.

RECHE, I., E. PULIDO-VILLENA, R. MORALESBAQUERO, E. O. CASAMAYOR. 2005. Does ecosystem size determine aquatic bacterial richness? Ecology, 86: 1715-1722.

ROTHSCHILD, B. J. \& T. R. OSBORN. 1988. Small-scale turbulence and plankton contact rates. J. Plankton Res., 10: 465-474.

SANTOS, M. C., E. P. RAPOSO, G. M. VISWANATHAN \& M. G. E. DA LUZ. 2004. Optimal random searches of revisitable targets: Crossover from superdiffusive to ballistic random walk. Europhys. Lett., 67: 734-740.

SAROS, J. E., S. J. INTERLANDI, A. P. WOLFE \& D. R. ENGSTROM. 2003. Recent changes in the diatom community structure of lakes in the Beartooth Mountain Range, USA. Arct. Antarct. Alp. Res., 35: 18-23.

SHLESINGER, M. F., G. ZASLAVSKY \& U. FRISCH (eds). 1995. Lévy flights and related topics in physics. Springer-Verlag, Berlin. 347 pp.

SHOTYK, W., D. WEISS, P. G. APPLEBY, A. K. CHEBURKIN, R. FREI, M. GLOOR, J. D. KRAMERS, S. REESE \& W. O. VAN DER KNAAP. 1998. History of atmospheric lead deposition since $12,370{ }^{14} \mathrm{C}$ BP from a peat bog, Jura Mountains, Switzerland. Science, 281: 16351640.

SMITH, I. M. \& D. R. OLIVER. 1976. The parasitic associations of larval water mites with imaginal aquatic insects, especially Chironomidae. Can. Entomol., 108: 1427-1442.

SMOL J. P. \& B. F. CUMMING. 2000. Tracking long-term changes in climate using algal indicators in lake sediments. J. Phycol., 36: 986-1011.

SMOL, J. P., A. P. WOLFE, H. J. BIRKS, M. S. V. DOUGLAS, V. J. JONES, A. KORHOLA, R. PIENITZ, K. RUHLAND, S. SORVARI, D. ANTONIADES, S. J. BROOKS, M. A. FALLU, M. HUGHES, B. E. KEATLEY, T. E. LAING, N. MICHELUTTI, L. NAZAROVA, M. NYMAN, A. M. PATERSON, B. PERREN, R. QUINLAN, M. RAUTIO, E. SAULNIER-TALBOT, S. SIITONEN, N. SOLOVIEVA \& J. WECKSTROM. 2005. Climate-driven regime shifts in the biologi- 
cal communities of arctic lakes. Proc. Nat. Acad. Sci., 0500245102.

SOLOVIEVA, N., V. J. JONES, P. G. APPLEBY \& B. M. KONDRATENOK. 2002. Extent, environmental impact and long-term trends in atmospheric contamination in the Usa basin of east-European Russian arctic. Wat. Air Soil Pol., 139: 237-260.

SOMMARUGA, R. 2001. The role of solar UV radiation in the ecology of alpine lakes. $J$. Photochem. Photobiol., 62: 35-42.

SOMMARUGA, R., \& R. PSENNER. 1997. Ultraviolet radiation in a high mountain lake of the Austrian Alps: Air and underwater measurements. Photochem. Photobiol., 65:957-963

SOMMARUGA, R., B. SATTLER, A. OBERLEITER, A. WILLE, S. WÖGRATH-SOMMARUGA, R. PSENNER, M. FELIP, LL. CAMARERO, S. PINA, R. GIRONÉS, \& J. CATALAN. 1999. An in situ enclosure experiment to test the solar UVB impact on plankton in a high mountain lake: II) effects on the microbial food web. J. Plankton Res., 21: 859-876.

SORVARI, S. \& A. KORHOLA. 1998. Recent diatom assemblage changes in subarctic Lake Saanajärvi, NW Finish Lapland, and their paleoenvironmental implications. J. Paleolimnol., 20: 205-215.

STERNER, R. W. \& J. J. ELSER. 2002. Ecological stoichiometry. Princeton University Press. Princeton. 439 pp.

STUIVER M., T. F. BRAZIUNAS, P. M. GROOTES \& G. A. ZIELINSKI. 1997. Is there evidence for solar forcing climate in the GISP2 oxygen isotope record? Quaternary Res., 48: 259-266.

THE MOLAR WATER CHEMISTRY GROUP. 1999. The MOLAR project: atmospheric deposition and lake water chemistry. J. Limnol., 58: 88-106.

TIMM, T., 1980. Distribution of aquatic oligochaetes. In: Aquatic Oligochaete Biology. Brinkhurst, R.O. \& D.G. Cook (eds): 55-77. Plenum Press, New York.

TSIOURIS, S., C. E. VINCENT, T. D. DAVIES \& P. BRIMBLECOMBE. 1985. The elution of ions through field and laboratory snowpacks. Ann. Glaciol., 7: 196-201.

VALLS-TABERNER, F. 1988. Privilegis $i$ ordinacions de les valls dels Pirineus: Vall d'Àneu, Vallferrera and Vall de Querol. Promociones y Publicaciones Universitarias. Barcelona. 375 pp.

VAN DE VELDE K., C. BARBANTE, G. COZZI, I. MORET, T. BELLOMI, C. FERRAR \& C.F. BOUTRON. 2000a. Changes in the occurrence of silver, gold, platinum, palladium and rhodium in Alpine ice and snow since the eighteenth century. Atmos. Environ., 34: 3117-3127.

VAN DE VELDE K., C. F. BOUTRON, C. FERRARI, A.-L. MOREAU, R. J. DELMAS, C. BARBANTE, T. BELLOMI, G. CAPODAGLIO \& P. CESCON. 2000b. A two hundred years record of atmospheric cadmium, copper and zinc concentrations in high altitude ice from the French-Italian. Alps. Geophys. Res. Lett., 27: 249-252.

VAN DROOGE B. L., J. O. GRIMALT, L. CAMARERO, J. CATALAN, E. STUCHLIK \& C. J. TORRES GARCÍA. 2004. Atmospheric semivolatile organochlorine compounds in European highmountain areas (Central Pyrenees and High Tatras). Environ. Sci. Technol., 38: 3525-3532.

VENTURA, M., L. CAMARERO, T. BUCHACA, F. BARTUMEUS, D. M. LIVINGSTONE, \& J. CATALAN. 2000. The main feature of seasonal variability in the external forcing and dynamics of a deep mountain lake (Redó, Pyrenees). $J$. Limnol., 59: 97-108.

VENTURA, M. \& J. CATALAN. 2005. Reproduction as one of the main causes of temporal variability in the elemental composition of zooplankton. Limnol. Oceanogr., 50: 2043-2056.

VISWANATHAN, G. M., V. AFANASYEV, S. V. BULDYREV, E. J. MURPHY, P. A. PRINCE, \& D H. E. STANLEY. 1996. Lévy flights search patterns of wandering albatrosses. Nature, 381: 413415.

VISWANATHAN G. M., S. V. BULDYREV, S. HAVLIN, M. G. E. DA LUZ, E. P. RAPOSOK \& H. E. STANLEY. 1999. Optimizing the success of random searches. Nature, 401: 911-914.

VIVES, I., J. O GRIMALT, J. CATALAN, B. O ROSSELAND \& R. W. BATTARBEE. 2004. Influence of altitude and age in the accumulation of organochlorine compounds in fish from high mountain lakes. Environ. Sci. Technol., 38: 690-698.

VIVES, I., J. O. GRIMALT, M. VENTURA \& J. CATALAN. 2005. Distribution of polycyclic aromatic hydrocarbons in the food web of a high mountain lake (Pyrenees), Environ. Toxicol. Chem., 24: 1344-1352.

WANIA, F. \& D. MACKAY. 1993. Global fractionation and cold condensation of low volatility organochlorine compounds in polar regions. Ambio, 22: $10-18$.

WARNECKE, F., R. SOMMARUGA, R. SEKAR, J. S. HOFER, \& J. PERNTHALER. 2005. Abundances, identity, and growth state of Actinobacteria in 
mountain lakes of different UV transparency. Appl. Environ. Microb., 71: 5551-5559.

WATRAS, C. J. \& J. F. HANEY. 1980. Oscillations in the reproductive condition of Diaptomus leptopus (Copepoda, Calanoida) and their relation to rates of egg-clutch production. Oecologia, 45: 94-103.

WHITEHOUSE, J. W. \& B. G. LEWIS. 1973. The effect of diet and density on development, size and egg production in Cyclops abyssorum. Crustaceana, 25: 225-236.

WOESE, C. R. 1987. Bacterial evolution. Microbiol. Rev., 51: 221-271

WOLFE, A. P., A. C. VAN GORI \& J. S. BARON. 2003. Recent ecological and biogeochemical changes in alpine lakes of Rocky Mountain National Park (Colorado, USA): a response to anthropogenic nitrogen deposition. Geobiology, 1: 153-168.
WRIGHT, R.F., T. LARSSEN, L. CAMARERO, B. J. COSBY, R. C. FERRIER, R. HELLIWELL, M. FORSIUS, A. JENKINS, J. KOPÁCEK, V. MAJER, F. MOLDAN, M. POSCH, M. ROGORA \& W. SCHÖPP. 2005 Recovery of acidified European waters. Environ. Sci. Technol., 39: 64A$72 \mathrm{~A}$.

YOUNG, J. O. \& T. B. REYNOLDSON, 1999. Continuing dispersal of freshwater triclads (Platyhelminthes; Turbellaria) in Britain with particular reference to lakes. Freshwat. Biol., 42: 247-262.

ZWART, G., B.C. CRUMP, M. P. KAMST-VAN AGTERVELD, F. HAGEN \& S. K. HAN. 2002. Typical freshwater bacteria: analysis of 16S rRNA from plankton of lakes and rivers. Aquat. Microb. Ecol., 28: 141-155. 